Article

\title{
The Significance of Civil Intellectuals' Activism: A Case of Eco-Nationalistic Social Movement in Bangladesh
}

\author{
Moshreka Aditi Huq ${ }^{1,2}$ \\ 1 Graduate School for International Development and Cooperation, Hiroshima University, 1-5-1 Kagamiyama, \\ Higashi Hiroshima 739-8529, Japan; aditihuq9@gmail.com \\ 2 Department of Anthropology, Faculty of Social Sciences, University of Chittagong, Chittagong, Bangladesh
}

Received: 13 December 2019; Accepted: 6 February 2020; Published: 8 February 2020

check for updates

\begin{abstract}
This article examines how the civil intellectuals of Bangladesh oppose the state-sponsored political imposition that consistently approached to establish a coal-fired power plant, thus, risking the Sundarbans-one of the world's largest mangrove forests. By incorporating five points of significance, this article argues that civil intellectuals, as the only acceptable spokespersons, not only play a vital 'counteracting' role in differing the government's adamant decision, but also are impeded by their functional limitations. This study appraises the position of civil intellectuals in this movement through using intensive interviews, focus group discussions, and participation-observation. The results find that civil intellectuals: (1) respond to governmentality by producing counter-discourse and are struggling state hegemony through the phases of the movement; (2) conceive an eco-nationalistic ideology that is in contrast to the state's development-nationalistic motives; (3) oppose sense of eco-governance by offering scientific counter-discourse; (4) are revealed as having significant functional limitations in associating with local people from the affected area; and (5) are inherently political entities, whose identity is understood through their reflective functional behavior. The study suggests that civil intellectuals need to solve the constraints of 'theory' and 'practice' to gain ultimate success in operating social resistance to oppose issues of injustice.
\end{abstract}

Keywords: civil intellectuals; social movement; counter-discourse; governmentality; hegemony; power; resistance; activism; cultural nationalism

\section{Introduction}

The Sundarbans, one of the largest mangrove forests (Figure 1) in the world, lies on the channel of the three mainstream rivers (the Ganges, Brahmaputra and Meghna) on the Bay of Bengal. It is inscribed as a World Heritage site in 1987. Since 2010, the Bangladesh government, in partnership with India, has been working to establish a 1320-megawatt coal-fired power station at Rampal Upazila ${ }^{1}$ in the Bagerhat District of Khulna, Bangladesh. The joint partnership, known as the Bangladesh-India Friendship Power Company (Pvt.) Limited (BIFPCL) ${ }^{2}$ involves India's state-owned National Thermal Power

1 Refers to a sub-district: these function as sub-units of districts in Bangladesh. The upazila is an administrative region in Bangladesh which was previously known as a thana.

2 A power company that comprises a 50:50 joint venture between India's National Thermal Power Corporation (NTPC) and the Bangladesh Power Development Board (BPDB). This private company is incorporated under the joint venture agreement executed between BPDB and NTPC on 29 January 2012. 
Corporation (NTPC) $)^{3}$ and the Bangladesh Power Development Board (BPDB) ${ }^{4}$ [1]. The proposed power plant project is situated only $14 \mathrm{~km}$ north of the world's largest mangrove forest, the Sundarbans (Figure 2). Nevertheless, the current Bangladesh government believes that the proposed plant will be the country's largest electricity-generating power plant, incorporating modern and efficient technology by importing coal of high calorific value (average gross calorific value [GCV] $5700 \mathrm{kcal} / \mathrm{kg}$, low sulfur, and low ash content) [2]. The project, with its two phases of construction and shelving, is projected for 2022. The financing sources of this power plant are the NTPC and the BPDB that are jointly giving 30\%, along with the Exim Bank of India, that is investing 70\% of the total cost [3]. Conversely, scientists and environmentalists increasingly suspect that this harmful initiative will destroy the whole mangrove forest and its unique ecosystem. This project already violates the environmental impact assessment (EIA) guidelines for coal-based thermal power plants. Most of the impacts of this coal-fired power plant, when investigated, have been found to be harmful and irreversible for biodiversity [4-7].

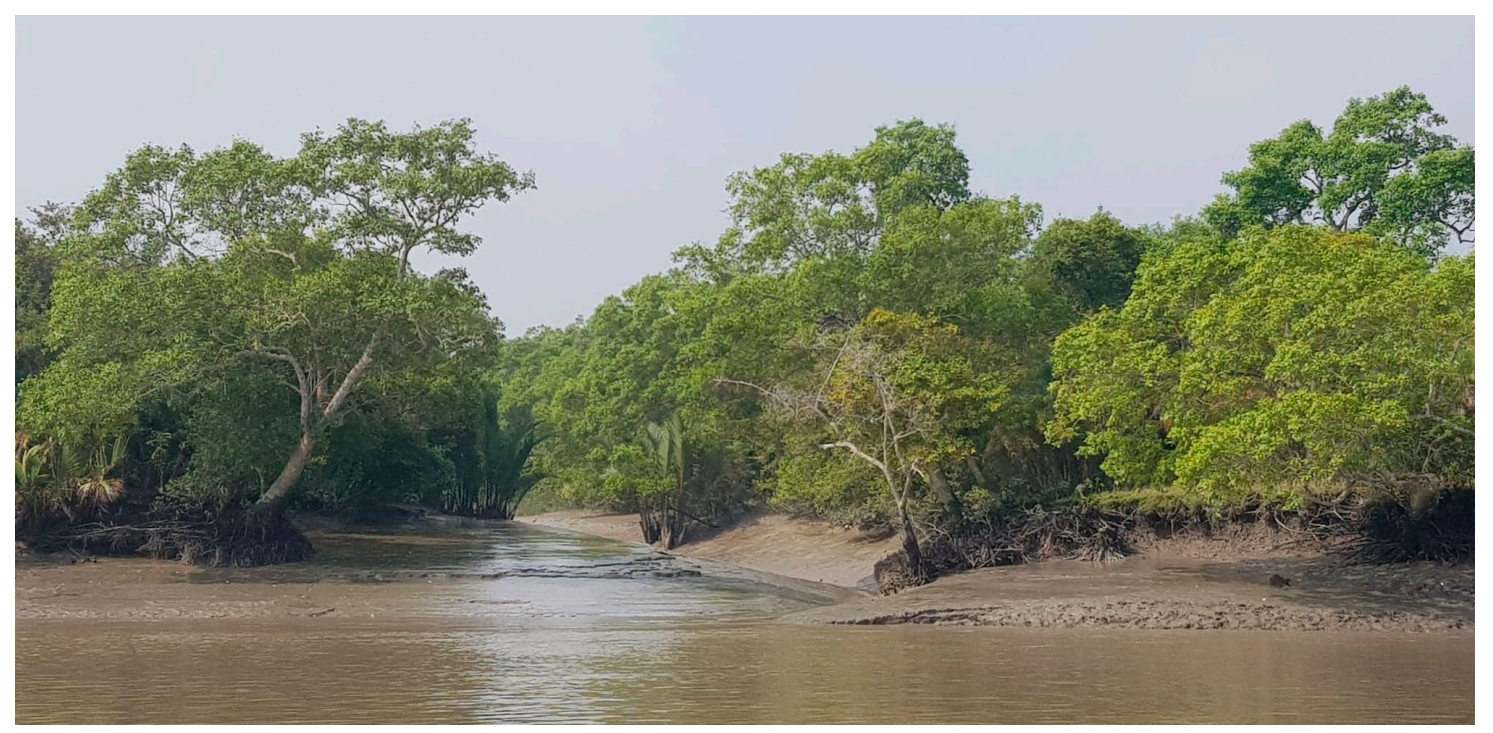

Figure 1. Image of the mangrove forest, the Sundarbans. Source: Author's fieldwork (February 2018-March 2019).

3 The NTPC, or NTPC Limited, is an Indian business group that generates electricity and undertakes allied activities. This company is also engaged in gas exploration and coal mining projects.

4 Belonging to the Bangladesh Ministry of Power, Energy and Mineral Resources, the Bangladesh Power Development Board (BPDB) performs as a public sector organization to boost the country's power sector. 


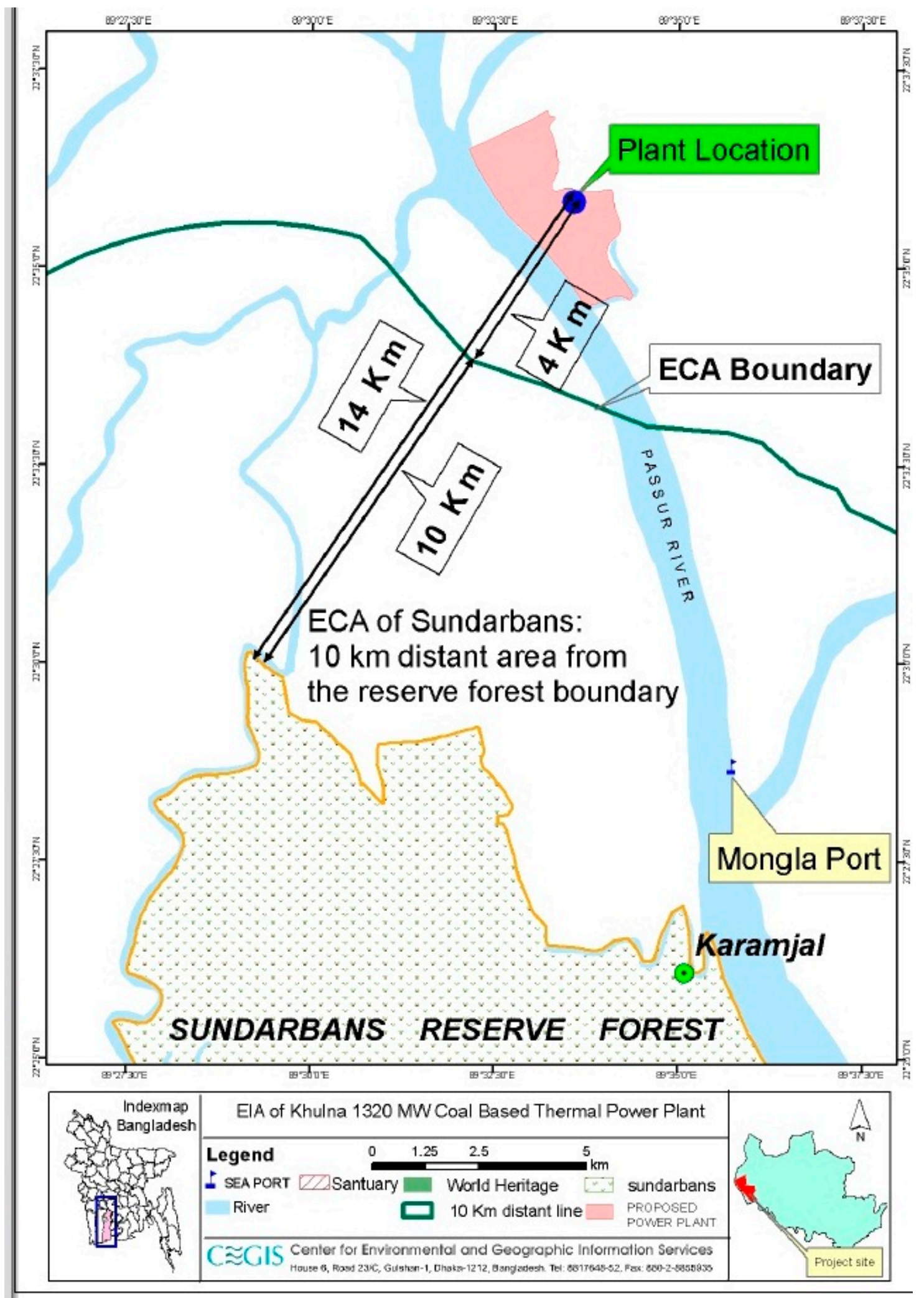

Figure 2. Distance between the Sundarbans and Rampal power plant [8]. 
Thus, along with other bodies of 'civil intellectuals' 5 and civil alliance groups, since 2012, the National Committee to Protect Oil, Gas and Mineral Resources, Power, and Ports of Bangladesh (hereafter 'National Committee') ${ }^{6}$ has been involved in the Sundarban-Rampal Anti Power-Plant Movement's protest and campaign countering this India-Bangladesh joint-venture coal-based power plant to be located near the forest, the Sundarbans. Consisting of members from the National Committee and different activist organizations, and various intellectual activist representatives from a wide range of civil intellectual categories in Bangladesh, the running movement upholds its continuous struggle against the government's decision regarding the establishment of this coal-fired power plant for generating electricity. Their stance argues that the power plant will destroy Bangladesh's only mangrove forest, the Sundarbans [9,10]. As stated by Reference [11], the National Committee does not oppose the extraction and use of coal for the plant; instead, it opposes choosing the site as it has potentially devastating effects on the Sundarbans. The National Committee also criticizes India's motives, as India does not allow similar power plants near its own ecologically fragile areas. In the initial stage, the movement was a result of the primary reaction which began after the announcement of the contract between the Bangladesh government and India to establish the power plant. Then the collective struggles occurred as a preparatory phase. Later, the movement comprised protest activities with an interval for the national election and the post-election reaction. Afterwards, the movement gained rigorous speed in its manifestation. Although the movement began to appear a little slow and mild, the force factors were the processes towards resettlement and reconstitution, particularly from April 2017 to the present time (author's fieldwork, February 2018-March 2019). Therefore, the article describes the significance of activism by the civil intelligentsia in Bangladesh through this case of a social movement. The Sundarban-Rampal Anti Power-Plant Movement has been selected, due to its dynamic social aspects. It appears to have the potential to identify the strengths and weaknesses of civil intellectual activists in Bangladesh in struggling the state-sponsored political imposition.

Many scholars have recognized that the social movement represents a cluster of opinions and beliefs of a group that contributes to resistance and changes, initiating the clear identification of opponents acting in an identical type of an organization, and extracting its historical shift [12,13]. Elaborating on previous works by References [12,14-16]; Charles Tilly, cited in References [17-20] focused on the social movement as it is a combination of the principle of identity, the principle of opposition, and the principle of totality. Subsequently, Reference [21] discussed social movements in terms of understanding collective action towards its functionality in protest. Although the Sundarban-Rampal Anti Power-Plant Movement helps to identify the cause of the severe future dispossession of local

5 The key term 'civil intellectuals' has been used throughout the article to blend the categories of activists coming from both civil and public intellectual groups whose protest origins and resistance were initiated in the urban and capital city spheres of Bangladesh, particularly in the case of the Sundarban-Rampal Anti Power-Plant Movement. The term 'civil intellectuals' refers to the conscious entities coming from various civil professions, non-governmental organizations, non-state actors, representatives of agencies and institutions, NGO vocals, social personalities, independent intellectuals, educators, researchers, writers, activists, policymaking vocals, authorized public figures, environmentalists and many who work being aware and functionally active. For this case, civil intellectuals is considered as a unified term; coined, due to two features of being civil/urban in habitats, as well as functioning through intellectually active behavioral reflections for the movement. In this research, the selected interviewees were found in a merged cluster in the society where they tend to carry the alliance with the suppressed and where they acted publicly, as well as organically in organizing political-cultural demonstrations; something like Antonio Gramsci noticed the "intellectuals with mass formation and left tendency" [Please see Buci-Glucksmann, C. Gramsci and The State. D. Frenbach. (Trans.). Lawrence and Wishart: London, 1980, pp. 24-36.]. In this study, the major attention was on National Committee Bangladesh (NCBD) to Protect Oil Gas Mineral Resources Power and Ports which is an official committee for organizing the Sundarban-Rampal Anti Power-Plant Movement consisting of left-oriented organizations combining the representatives of these civil Intellectuals. All the entities together, as clustered are identified as 'civil intellectuals.'

6 The full name is the National Committee to Protect Oil, Gas and Mineral Resources, Power and Ports or the National Committee Bangladesh (NCBD). It is an official committee and the only vital platform for organizing the Sundarban-Rampal Anti Power-Plant Movement consists of progressive left-oriented parties along with representatives of civil intellectual bodies like environmentalists, educators, researchers, writers, journalists, lawyers, artists, and public intellectual activists, etc. The committee mainly runs continuous activism in the capital Dhaka as considering the city as their central platform. Besides, they have few branches and regional representative committees to execute activism in other parts of Bangladesh, including adjacent areas to the southern zone; consisting the Sundarbans. 
people by their government, it also functions as a social movement fighting the issues like coal business, deforestation in the name of development, and the country's flawed national energy policies. The management of energy issues, significantly coal mining and its market-related social tensions, are widely discussed in previous case studies [22-27] from the perspectives of neoliberalism and political ecology.

Regarding the earlier history of a social movement, the Bangladesh Liberation War, 1971 was the prime movement initiative taken by the mass people of East Pakistan (Present Bangladesh) against the mass genocide on 25 March 1971 and army regime of West Pakistan where the civil intelligentsia played an enormously significant role accomplishing national liberty. Later, for several decades and particularly for the last 15 years, Bangladesh has experienced the immense and dynamic participation of civil intellectual activists in various social uprisings. The 2006 Phulbari Coal Resistance that mobilized protest initiatives to confront transnational ties [24,28]; the 2013 Shahbag Protests reflecting Bangladeshi nationalism and political forces [29-31]; the 2015 Bangladeshi student protests against value-added tax (VAT) on education in relation to neoliberal education policies [32]; and the 2018 Bangladesh road-safety protest [33] are recent examples of the presence of civil intellectuals' activism ${ }^{7}$ in the country's knowledge function. In criticizing the state's authoritarian decision, the Sundarban-Rampal Anti Power-Plant Movement characterizes the movement's intellectual struggle upholding the identification of their counter-discourse and the counter-hegemonic role that questions the political imposition.

In the investigation, this research article combines 'civil' and 'intellectuals' in the unified term 'civil intellectuals', due to the merging tendencies that operate from their different cultural class existences of society towards social activism. These civil intellectuals are consistently making social critiques and assessments regarding the ongoing systems in terms of democratic sustainability and political oppressions in various cases. Though varying in ideological positions, their inner alignments towards major eco-nationalistic issues are active on the common platform according to their belief for the country's welfare. Since struggling with the autocratic military regime in the '80s; civil intellectuals of Bangladesh began to protest against a series of undemocratic political practices that continues until the present time. In this journey of past several decades; the pioneers and their forerunners had been speaking up as the politically conscious vocals in questioning authority. Representing a form of 'cultural nationalism ${ }^{8}$; these entities tend to offer persistent critiques on socio-political policies in these given contexts. As the Sundarban-Rampal Anti Power-Plant Movement conceptualizes the unique features of environmental, national, political, economic, and cultural aspects, this movement case is assumed to be a suitable example for examining this specific purpose. To vary the inquiry, this discussion identifies the five major points of significance of this movement, constructing the proposition which is rationalized according to the empirical data. The study follows the anthropological research techniques entirely using qualitative methods. In the initial stage, the study is intended to explain the birth of the event, so that the section recounts a brief background along with describing the theoretical construction and methodology. This article then leads to the fundamental proposition, which further describes the five points of significance as results. To argue for these points, a set of theoretical approaches is adopted, due to the multifaceted features of the movement. Thus, for this article, one fundamental proposition leads the entire discussion incorporating the five points of significance.

With the use of the term 'civil intellectuals' activism', this article refers to the responses of the civil intelligentsia as a group to the social movement, with this manifested in their intellectual struggles through various cultural and political demonstrations.

8 In this article, the term 'cultural nationalism' refers to a form of symbolic belief pattern of the intellectual entities whose motivation and their offered narratives influence the method of activism. This pattern describes the sense of intellectuals' sensitivity regarding the location of created cultural hegemony. Even not being the part of the state's power hegemony very directly, this narrative discourse of intellectuals can produce hegemonic cultural language that can make influences in society. This capability gives them a nationalist image, somewhat culturally. In this connection also Homi. K. Bhabha sounds quite relevant as he discussed this issue regarding the cultural constructions of 'nationness' where the nation is seen as the holistic cultural entity [Please see Bhabha, H.K., The Location of Culture. Routledge: London \& New York, 1994, pp. 139-170.]. 
The rudimentary proposition argues that, in the Sundarban-Rampal Anti Power-Plant Movement (a movement against the establishment of a disastrous coal-fired power plant by the government of Bangladesh), particular entities of civil intellectuals, as the only satisfactory option of being active agents, play the vital role dissenting the government's adamant and sponsored imposition, along with some functional limitations. Under this proposition, it argues that in dealing government's political imposition, civil intellectuals generate a 'counteracting' position in this movement. To prove this argument, the article reflects on the foremost point of significance of civil intellectual activism for the movement in this case. The article conceives of five specific implications, deliberating on (1) responding governmentality ${ }^{9}$ - how civil intellectual activism responds to the state-sponsored political imposition and governmentality in the processes of the movement; (2) recognizing eco-nationalistic strength-it explains how civil intellectual activism holds eco-nationalistic emotion in the movement, that contradicts the given rationale of development-nationalism by the current government; (3) dissenting authority's sense of eco-governance-it argues for their concerns about the associated eco-political affairs and scientific discourse; (4) questioning existential limitations-it seeks the degree of the involvement of civil intellectual activists with local people, indicating their functional limitations; and finally, (5) finding civil intellectuals as a set of assembled thought entities producing counter-discourse and counter-hegemony - which tries to locate activists in a new formation of the political and cultural class concoction.

\section{Conceptual Perspectives: Compartmentalization in Connectivity}

Due to the specific patterns of this movement and the contextual functionality of civil intellectuals of Bangladesh, this article applies a composed set of connecting theoretical approaches for conceptual structure. Incorporating the interpretations of five significances belonging to the main argument, the article uses the theoretical notions of Michel Foucault's notable works on the analysis of discourse, governmentality and eco-governance; as well as Gramscian view of hegemony-counter hegemony and intellectuals. Moreover, it also discusses questions of subalterns in social movement issues.

Foucault's coined term "discourse" is known to us as the set of an abstract system of thoughts, a unique approach in terms of indexing something critically with knowledge production, inevitably again within power relationships [34-37]. In their study, Reference [38] argues that discourses can shape people's subjectivity and play roles to mobilize the potential for a social movement. Discourses function in contestation, along with forming dominant and counter-discourses [39]. The relevance of using the term "discourse" in this study is to show the integrated condition of power and knowledge complying each other in the context. Relating the notion of discourse to the empirical evidence, this study shows how the actors like the government and civil intellectuals, formulate own discourse rationales and counters on the scientific dispute platform with the use of knowledge and power in the movement.

Foucault emphasized the ways in which a state's administrative organizations become able to control and regulate the masses through technologies and surveillance means as tools for exercising power in their established bureaucratic contexts [37]. As Gramsci understood hegemony [40] and its' in built authority within power [41]; thus, to explain "governmentality"; Foucault, highlighted the target population, the rulers' knowledge of political economy, the sense of maintaining security, specific governmental apparatus, the implications for justice and the administration and the notion of 'biopower' (Foucault, cited in Reference [42]). This biopower was referred to the concentrated large formation of controlling techniques to obtain the subjugation of bodies by mastering. In The History of Sexuality, part 1, Foucault argued that a historic shift of power occurred in the eighteenth century, where power transformed into a modern mode over the production of life (biopower) in a politically

9 This term, originally developed by Michael Foucault, applies when the government tries to shape people to fulfill its policies and organizes practices, such as mentalities, rationalities, and techniques. In other words, it becomes the art of governance. 
institutional age from the then-pre-modern control over the ending of life, such as through family institutions (Foucault, cited in Reference [43]). Defying the term biopower, Reference [44] argued the viewpoint of biopolitics, as biopower can be seen as hegemonic struggles to gain an understanding of body politics in the imposed process of social normalization. According to Reference [45], the 'race' became associated with the "sciences and technologies of the social" that were emerging as part of biopolitics.

However, in experiencing the idea of governmentality, which shapes action, as well as freedom [46], Foucault comprehended the notion of power. Improvising this concept of Foucault, in the result sections, this article shows how the government had become able to establish the Rampal Power Plant near the forest without getting massive protests from local masses. Despite having dissents from protesters like civil intellectuals, the government seemed to have their usual political control. To manifest it, various factors like the local people's belief in development, assurance of job facilities, given promises for expanding urban areas and business in the southern zone, constant official campaigns-advertisement, and regulated administrations were useful for controlling the whole scheme and its management. The entire process also portrays the art of the governance, where it attempts to normalize the concept of 'development.'

In the case of Sundarban-Ramapl Anti Power Plant Movement, the argument of eco-governmentality seems relevant in various ways. Discussion on environmentalism and ecological justice appeared more obvious when empirical data and practical experiences showed that all people do not suffer equally from the effects of environmental degradation worldwide [47]. Since the late 1960s, like other rising waves that challenged authority, promoting the counter-culture and the civil rights struggle, the movement of the environmental issue occurred steadily and significantly [37]; [48-50]. The resistance of the Sundarban-Rampal Anti Power-Plant Movement indicates the tendency of the state's prioritized neoliberal policy that is affecting natural resources, and perhaps can be best understood by the phrase "governing the nature" [51]. Furthermore, this article purposefully deals with the eco-nationalistic emotion argument of civil intellectuals, as it dominantly functions in this movement and similarly leads to their conscious discursive attributes and perception for eco-political affairs. It identifies their steps to take a nationalist stand, at the same time, the way they subjectify the movement. It is argued by Reference [52] that this kind of nationalism as an ideology promotes a collective consciousness and identity (Anderson, cited in Reference [52]) which speaks in favor of meeting a specific political agenda in their execution of resistance. This study questions the environmental governance and its system for maintaining accountability. The case shows how the state tries to be governmental, maintaining a set of relationships among the bodies of government themselves, the business sector, civil society, and the masses in the name of development. The government seems to make various neoliberal policies, eventually captivating public property and campaigns for so-called sustainability. As a critical explanation, Foucault's argument again leads to the idea that power itself works in assembly, that is, in 'power relations' [53]. Environmental governance indeed reveals that power and governance may use or abuse through every means of the elements, including even nature. In his understanding of power ties, Foucault states that: "Power relations can materially penetrate the body in-depth, without depending even on the mediation of the subject's representations" (Foucault, cited in Reference [53]).

The attributes of the governmentality approach and its authoritarian artistic component perhaps fuel our understanding of "hegemony", the foundation of the ruling class found by Gramsci which confirmed the state's force, not only in its application, but also in discussion of its proposed set of ideas for the people. After analysis of Marx on the state and its economy, Gramsci's term "hegemony" was also introduced in the arguments and writings of Plekhanov, Axelrod, Lenin, and others [40]. Emphasizing the dominant culture as a tool for hegemonic practice as it gradually grasps the less powerful groups in the terrain of forming a hegemonic ideology, Reference [41] saw hegemony as a process through which power is naturally considered an authority. In this article, as the main proposition argues about civil intellectuals' 'counteracting' position; it seeks them in ability for creating a 'counter-hegemony' through 
their activism for the movement. Through the data, the study intends to show that to counter the government's given rationale, the civil intellectual representatives also form a type of counter-hegemony through their narratives and intelligent manners in movement. Additionally, influenced by Gramscian theoretical analysis on intellectuals, the present article explores 'civil intellectuals' who are intellectuals, but rather has shaped as some new representative communicating identities, beyond the previous concepts for 'traditional' or 'organic' ${ }^{10}$ categories of intellectuals. Intellectuals were regarded as the essential mediating functionary bodies in the struggle of class forces (Gramsci, cited in Reference [54]). Therefore, in the case of Bangladesh, this article identifies active civil intellectuals as an entity of concoction beyond identifiable categories, even classes; transporting counter-rationales opposing state dominance in the collective sphere and ensuring "conscious activeness."

The article argues that in the Sundarban-Rampal Anti Power-Plant Movement, civil intellectuals appear to have less efficiency in their organizational qualities which ultimately explains their significant weakness in consolidating the engagement of local people (considered as the 'subaltern masses') with the movement. Gramsci's view on intellectuals [54]; Spivak's subaltern quests [55,56]; subaltern discourses [57,58]; Foucault's view regarding "civil society as transactional reality" [59]; and the idea of "subjugated knowledge" [60]; were useful in the discussion. Foucault's understanding of them was as "they are not inherently progressive forces, but with real effects" [59], who are reasonably assumed as reflexive creation within the social history, generate counters that argue with governmental hegemony. In further discussion, the study shows that the subjugated truth and understanding of local people becomes shadowed, due to the hegemonic and counter hegemonic languages practiced by other actors in the society.

For Gramsci, civil society was described not as the sphere of freedom, but of the realization of hegemony, which is likely to be derived from 'consent.' As 'consent' does not often come from 'free choice,' it manufactures itself politically [61]. Relevantly, engaging intellectuals in the interactive dynamics of a social movement within power politics, Reference [62] discussed Doug McAdam, Sidney Tarrow, and Charles Tilly's expression as it summarizes the "activist's ideas forged in dialogue." Thus, through this study, this article offers an added perspective to this phrase as it sees the "activist's ideas forged in dialogue and action."

\section{Methodology: Gathering Data and Analysis}

To understand the significance of civil intellectuals' activism in the Sundarban-Rampal Anti Power-Plant Movement, this research entirely used the qualitative approach with an anthropological perspective. It followed the ethnographic style in saturating and analyzing data along with short-term engaged participation and long-term observation of the movement process. The study has undertaken two phases of exploration: (1) Empirical investigation; and (2) breaking down the data into the analysis.

Before starting the fieldwork and obtaining the primary empirical data, decisions had to be made on basic considerations for the study, such as the selection of a particular case, research sites; timeline; data-gathering techniques, gaining access; the degree of the researcher's involvement; and rapport building. In this process, case selection followed the dimensional features of the movement that would be multifaceted in the contexts of environmental security, intellectual resistance against contemporary political instability, authoritarian governance, and regional politics, including diplomatic relations with neighboring countries. The research sites were chosen comprised the capital of Bangladesh, Dhaka, where urban civil intellectuals lived; Rampal Upazila as the center of the proposed coal-fired power plant's location; and the local habitats of Mongla Upazila in the Bagerhat District near the deep mangrove forest, the Sundarbans. To carry out the intensive fieldwork took six months of physical

10 Traditional intellectuals refer to the economically and politically marginalized intellectuals within capitalism where organic intellectuals cannot be defined by their profession but to be understood by the social change they seek to initiate [(Historical Materialism. On Intellectuals, October 8, 2017. Retrieved from http://www.historicalmaterialism.org/blog/intellectuals) (Accessed on 20 January 2020).] 
presence at these sites. The fieldwork was conducted in three phases. The first phase was from February 2018 to March 2018; then, the second phase was between April 2018 and May 2018, and the third phase was between February 2019 and March 2019. Moreover, the observation is, at present, continuing.

The main three primary methods, consisting of an intensive interview, focus group discussion, and participation and observation, were used to gather the primary data. The intensive interviews were conducted informally [63] using a mostly conversational approach. Table 1 describes the representative numbers relevant to these three primary methods:

Table 1. Sources for Gathering the Primary Data.

\begin{tabular}{ccccc}
\hline & Dhaka (the Capital) & Rampal Upazila, Bagerhat & Mongla Upazila, Bagerhat & Total \\
\hline 1. Interviews & 24 & 11 & 14 & 49 \\
\hline 2. Focus Group Discussion & & 3 & 4 & 7 \\
\hline 3. Participation- Observation & 3 & & 3 \\
\hline \multicolumn{2}{c}{ Total Research Techniques } & & 3 \\
\hline & Source: Author's fieldwork, March 2018-March 2019.
\end{tabular}

In Table 1, it is found that the interviews were conducted with 24 civil intellectual entities belonging to the Sundarban-Rampal Anti Power-Plant Movement. All 24 interviews of this category were chosen from capital Dhaka based on the author's accessibility and purpose. As the center platform of this movement is Dhaka, all of these representatives came mainly from National Committee (central), several nationally registered groups of environmentalists, and different types of civil intellectual professional, such as educators, researchers, writers, journalists, lawyers, artists, progressive partisan allied members, and public intellectual activists. In Rampal Upazila and in Mongla Upazila, 11 and 14 people were chosen, respectively, coming from various professions, including government authorities and business sectors. They were selected based on earlier rapport building and personal communication. Moreover, before the interviews, lists of responsible interviewees were generated using geographical maps that encompassed the capital Dhaka, Rampal Upazila in Bagerhat where the power plant is to be located, and Mongla Upazila in Bagerhart.

Along with Dhaka, interviews were conducted at Rampal and Mongla as these points lead to the river paths of the main forest areas. The study tried to capture conversations with people from the affected area, including those who lived nearby to the proposed power plant. As it is seen in Table 1, the focus group discussions were seven in total, which was undertaken only at Rampal and among villagers from the local territory near Mongla, both in the Bagerhat district. These focus group discussions were conducted with the local people to gather their impressions and reactions about the issue and the movement, including their reflections and ideas on the government's plan for the Rampal power plant; activism and the presence of civil intellectuals; treatment by local authorities; and most importantly, their suggested initiatives for combating the predicted ecological changes. All interview sessions and focus group discussions strictly followed the research ethics; as the local professionals and masses seemed very willing to express themselves without any reservation. Three first-hand participation-observations were carried out in Dhaka city during the different movement demonstrations by civil intellectuals. During the author's fieldwork in Bangladesh, all the three-movement demonstrations were observed in the capital with participation. Arranged by the National Committee; 'a public gathering and speech' in front of national press club on 19 April 2018, 'a round-table discussion and opinion-exchange session' on 26 April 2018, and 'an urgent meeting' among committee members along with other allied representatives on 7 May 2018 were observed during the second phase of fieldwork by the author, herself. The sampling style for the intensive interviews and focus group discussions involved the use of purposive and snowball techniques. A bit contrarily, the selected demonstrations for participation-observation had to be chosen without any option as these were accessible and only available events happened during the time of fieldwork, as well as the author's physical presence in Bangladesh. The study collected several texts, official papers, and documents for further analysis and 
documentation. The field jottings and notes, maintaining checklists and logs, and personal voice and video records were also worthwhile for this purpose.

The second stage of breaking down the data incorporates ethnographic description with the implementation of a holistic view of the actors and their responses in the movement process. The limitations for conducting this type of research are a practical reality as it presents limited facts, where [64] also argues about the inherent partial nature of ethnography that can be improved by building ethnographic art to deliver the representational tact. In relation to the use of ethnography for cultural understanding [65] agrees on the importance of the event and place, which requires maintaining the originality of the event as much as possible in the description. Moreover, the current study employed secondary data from two categories of sources: (a) Information extracted from journals, personal archives, national newspapers, leaflets, pamphlets, brochures, books, reports, reviews, writing blogs, official websites, and electronic pages of social media; and (b) constructing the theoretical section, articles were sourced through database searches. The study incorporated several philosophical, theoretical and interdisciplinary perspectives extracted from fields of social sciences where the essential concepts are interconnected with each other.

\section{Questioning State-Sponsored Imposition: Civil Intellectuals' Eco-Nationalistic Mode of Activism and Its Significance for the Sundarban-Rampal Anti Power-Plant Movement}

In this section, the article attempts to discuss its main proposition by assessing the role of civil intellectuals in the Sundarban-Rampal Anti Power-Plant Movement. In its intriguing observations on the five points of significance, the study affirms the vibrant role of activists, while considering their functional limitations in the movement progression. Concerning the five points of significance, firstly, the research shows the nature of the intellectual activism that makes dissents to the state's sense of governmentality, ultimately manifested in imposition regarding the issue of implementing a coal-fired power plant near the Sundarbans. It also discusses civil intellectuals' functional tendency in delivering counter-discourse and their counter-hegemonic role towards authoritarian governance. The second point signifies the eco-nationalistic ideology of civil intellectuals in pursuing their concerns about protecting natural wealth, such as the Sundarbans, which inevitably goes against the will of the present government in the matter of a power plant near the mangroves. The third point of significance refers to the awareness of civil intellectuals regarding the eco-political affairs of Sundarban-Rampal Anti Power-Plant disputes where it struggles with the presence of 'controlling' eco-governance. The fourth point of importance aims to critically understand the civil intellectuals' activism as it questions their organizational capacity, which seems inadequate for incorporating local people (subalterns) sufficiently into the movement. Fifthly, for this case, in regard to struggling governmentality and state hegemony, these civil intellectuals are observed to be the entities providing a sense of cultural nationalism, also seen as a concoction of assembled existences. On this issue, they seem to be the only effective spokespersons protesting against state-sponsored imposition through the Sundarban-Rampal Anti Power-Plant Movement; where there are no other equal and effective alternative voices. Describing five subsections, this portion of the article leads to the results obtained from the first-hand data.

\subsection{Civil Intellectuals in Social Action: Discourses and Response to Governmentality}

This subsection focuses on the process of activism by civil intellectuals in the Sundarban-Rampal Anti Power-Plant Movement. It shows how the activists' response through their intellectual resistance, generated through their logical discourse that deals with energy policy governance and ruling initiatives, which are ultimately seen as 'governmentality.'

Foucault states that discourses could not be seen without power relations, nor could they be understood as a result of sovereign and creative human minds [37]. Thus, for the context of this study, discourses are seen from the perspectives of its critical analysis. This study argues that the power of having discursive influence can be counted equally to other social resources to which not everyone has access. According to Reference [66], patterns and strategies of discursive access might be applicable for 
dominant social domains, institutions, professions, situations, and genres. It was also recognized by Reference [67] that the elements of the alternative discourse of power have certain social practices in the construction of systems of thought. Where an exercise of power is present, discursive propaganda is used through social mediums to make constructed reality, also by subjectifying the targeted population.

Data show that, in justifying the Rampal coal-fired power station, the Bangladesh government has campaigned and offered relevant scientific facts through its agencies. The Rampal coal-fired power station is to cover an area of over 1,834 acres of land and is situated $14 \mathrm{~km}$ north of the world's largest mangrove forest, the Sundarbans which are a United Nations Educational, Scientific and Cultural Organization (UNESCO) World Heritage site. With the project name of 'Maitree Super Thermal Power Project' $(2 \times 660$ megawatts [MW]), BIFPCL is currently building the plant where the site is located about $23 \mathrm{~km}$ south of Khulna City and $14 \mathrm{~km}$ north of Mongla Port of Rampal Upazila in Bagerhat District, Khulna Division, Bangladesh (author's fieldwork February 2018-March 2019). Using imported coal, BIFCPL proposes to extract saline water from Pussur River to meet its requirements for cooling water and sweet water for potable water, plant service water, cycle make-up (demineralized [DM] water), etc. It has been decided that the water is to be used again in the desalination process from saline water through the reverse osmosis process [2]. The environmental impact assessment (EIA) report was approved by the Department of the Environment (DOE), Bangladesh, on August 5 2013, based on the report by the Center for Environmental and Geographic Information Services (CEGIS), which was entrusted by the BPDB to conduct the EIA and the overall evaluation that presented positive results [68]. That is how the present government tries to offer their scientific rationales. Providing the counter-argument, Reference [8] confirmed the EIA indicated that most impacts of the coal-fired power plant would be negative and irreversible (-81) which could not be mitigated in any way for the mangrove Sundarbans. Very recently, the World Heritage Centre of UNESCO has placed the Sundarbans on the endangered World Heritage list with its objections about the power plant being constructed by the Bangladesh government at the edge of the forest [69]. However, ignoring all the facts, the concerns of protesters and environmentalists, rigorous protests, and continuous counter-arguments of the Sundarban-Rampal Anti Power-Plant Movement forum, the Bangladesh government appears to be obstinate in its intention to build and run the plant. The government has also allowed the construction of two additional power plants on the Payra River and frequently approves industrial projects on the periphery of the Sundarbans.

Moreover, the continuous undemocratic behavior of the current government of Bangladesh and the dominance of its present political regime has caused the situation to be more sensitive and questionable in many aspects. Despite describing the Sundarbans as the "lungs of Bangladesh," the Bangladesh High Court has recently asked the Department of Environment (DoE) to grant environmental clearance to three private companies. With this order, they can establish their factories in the Sundarbans Ecologically Critical Area (ECA) [70].

For the Rampal coal-fired power plant, the government retains its stance, offering the rationale of energy development, with the belief to be the most significant power source station for meeting the vast electricity demand of the people. If observed critically, the dispute is not only about the issue of a simple justifiable way of producing energy, as it is also a matter of initiating environmental risks along with uneven strategic relationships ${ }^{11}$ between Bangladesh and India, and includes concerns

11 For this particular case study on Sundarban-Rampal Anti Power-Plant Movement, uneven strategic relationships between Bangladesh and India refers to their unequal bilateral engagement and diplomatic policies regarding Sundarban-Rampal Power Plant, where the practical interest of Bangladesh is lower than India. Promoting private sector investment and emphasizing building regional energy markets, present government of Bangladesh is trying to make a regional power pool with the help of India [(Please see IAEA. Report on the Country Nuclear Power Profiles, Bangladesh, 2016. Retrieved from https://www-pub.iaea.org/MTCD/Publications/PDF/cnpp2019/countryprofiles/Bangladesh/Bangladesh.htm (Accessed on 18 January 2020)]. Thus, naturally the inevitable questions arose regarding using of dumped coal exported from India and using ecologically sensitive area like the Sundarbans for the plant. On this basis, continuously questions are coming from the experts on this disputed power projects [(Please see Center for Policy Dialogue. A Report on the Power and Energy Sector of Bangladesh: Challenges of Moving beyond the Transition Stage, Bangladesh, 2019) (Retrieved from 
about the neoliberal market policies. Although neoliberalism is seen as "the elevation of market-based principles and techniques of evaluation to the level of state-sponsored norms" (Davies, quoted in Reference [71]), it also indicates the opening up of new markets in public services [72] where the government itself becomes the campaigner for these types of businesses. In this conversation, the thoughts of Foucault become evident when he explores neoliberalism as a new technique for rationality to govern human beings with newly invented forms of human conduct shaped by the market (Foucault, cited in Reference [71]). As a result, in many cases, the governors of developing countries fascinatingly become special agents for more significant economic power play and trade.

After independence, Bangladesh gradually started practicing neoliberal resource governance with the help of foreign entrepreneurs. In these circumstances, Reference [11] shows how the National Committee has been engaged in a conscious intellectual struggle, with its members appearing as actors playing the role of counter-hegemonic discourse spokespersons struggling with the excessive neoliberal tendencies of the country's economy. The National Committee has a historical legacy of carrying out various protests since the end of the 1980s, in Bangladeshi context. Its protest agenda to date includes: Protesting against imperial multinational corporations; promoting a discursive battle on gas exports; protecting ports from the aggression of foreign investors; preventing corporate plundering; a rigorous movement against open-pit mining during the Phulbari occurrence in 2006; enhancing the anti-Tata campaign; protesting against ConocoPhillips with regard to gas exploration in the deep sea; opposing the government for signing production sharing contracts (PSCs) with several international oil companies (IOCs) to protect mass corporate interests in national resources [11]. Thus, opposing the India-Bangladesh joint venture coal-based power plant near the Sundarbans is actually the continuation of the protest tradition which encompassed other civil intellectual entities in the movement, such as representatives from the National Committee for Saving the Sundarbans (NCSS) ${ }^{12}$; the Bangladesh Environmental Lawyers Association (BELA) ${ }^{13}$; Poribesh Bachao Andolon (POBA) (or Save the Environment Movement [SEM] $)^{14}$; the Bangladesh Poribesh Andolon (BAPA) (or the Bangladesh Environmental Movement [BEM] $)^{15}$; Bam Morcha $(B M)^{16}$; Moulik Bangla $(M B)^{17}$; various activists; and some people belonging to the affected area. The Sundarban-Rampal Anti Power-Plant Movement is the National Committee's recent ongoing movement through which they are opposing the use of low-grade coal imported from India, as well as the site of the Rampal coal-fired power plant [9] (author's fieldwork February 2018-March 2019).

In 2013, the National Committee, along with environmentalist groups, bodies of the left-leaning parties, and the general population vowed together to resist the planned inauguration of the Rampal power plant (Haroon 2013, cited in Reference [73]). On September 24 2013, thousands of people in Bangladesh began a rally that lasted for five days. This 'long march' of them started in the capital city of Dhaka and slowly made its way to the world's largest mangrove forest, the Sundarbans. Owing to the continuous protest, different kinds of suppressive initiatives and violent actions were undertaken

https://cpd.org.bd/wp-content/uploads/2019/03/The-Power-and-Energy-Sector-of-Bangladesh.pdf) (Accessed on 18 January 2020)]. In this circumstance, the overall situation has created a constant tension towards the country's ecological affairs for the Sundarbans. It has been argued that through the establishment of the power plant in the southern region, the neighboring country India has gained wider access in their business in Bangladesh, as well as they could sell their low graded coal to the government. On the other hand, in spite of having the plan to generate electricity more, Bangladesh is losing its ultimate resource of mangrove forest Sundarbans. Therefore, it seems an uneven strategic relationship between these two neighboring countries so far.

12 The National Committee for Saving the Sundarbans (NCSS) is a civil organization formed by a coalition of more than 50 environmental organizations with its motive being to save the ecosystem and cultural tradition of the Sundarbans.

13 The Bangladesh Environmental Lawyers Association (BELA) provides advocacy for environmental justice.

14 Poribesh Bachao Andolon (POBA), or Save the Environment Movement (SEM), is a voluntary organization fighting eco-political conspiracy in national and international issues

15 Bangladesh Poribesh Andolon (BAPA), or Bangladesh Environmental Movement (BEM), is an organization that deals with environmental disaster issues, and comprises various types of environmental expertise and professionals.

16 Bam Morcha (BM) is an association of eight leftist partisan political groups.

17 Moulik Bangla (MB) is a group of young activists with the aim of working for the democratic liberty of the Bangladeshi people. 
by the government to stop the Sundarban-Rampal Anti Power-Plant Movement. The police force, using barricades, teargas shells, and batons, blocked a "Save the Sundarbans" march toward the Prime Minister's Office on July 28 2016, in which six people were arrested. This was organized in answer to the signing of an agreement to build the coal plant near the mangrove forest. Protesters dismantled two layers of police barricades before police deployed teargas shells and charged the demonstrators with clubs. As a result of this action, 16 activists were hospitalized [74]. According to the data, the whole Sundarban Anti-Rampal Movement can be divided into six essential phases, as shown below in Table 2, with their basic features.

Table 2. Phases and Features of Sundarban Anti-Rampal Movement.

\begin{tabular}{|c|c|c|}
\hline Phases of Anti-Rampal Protest Movement & Duration & Main Features \\
\hline 1. Primary reaction & January 2012-August 2013 & Confusion and understanding the issue \\
\hline 2. The initial stage of the movement & September 2013-December 2013 & $\begin{array}{l}\text { Agendas for activities, the long march, } \\
\text { political demonstrations }\end{array}$ \\
\hline $\begin{array}{l}\text { 3. Interval for the national election and } \\
\text { post-election reaction }\end{array}$ & January 2014-July 2015 & $\begin{array}{l}\text { Press release, public statement, mass } \\
\text { gathering, convention }\end{array}$ \\
\hline 4. Rigorous movement & October 2015-November 2016 & $\begin{array}{c}\text { Road march, police attacks, barricades, } \\
\text { engagement with UNESCO, strikes, } \\
\text { transnational protests, cultural } \\
\text { demonstration }\end{array}$ \\
\hline 5. Slow and mild & December 2016-March 2017 & Small declining tendency \\
\hline $\begin{array}{l}\text { 6. Stages of resettlement and } \\
\text { reconstitution }\end{array}$ & April 2017-present & $\begin{array}{l}\text { Evaluation, Transition and Reviving } \\
\text { (recently announced further tasks, } \\
\text { including the long term 'road march' for } \\
\text { upcoming September 2020) }\end{array}$ \\
\hline
\end{tabular}

Source: Author's fieldwork, February 2018-March 2019; Author's observation (ongoing), October 2017- Present

The first phase was 'primary reaction' which began after the announcement of the contract between the governments of Bangladesh and India to establish the power plant. This phase occurred from January 2012 to August 2013. The second phase, named as the 'initial stage of the movement,' was between September 2013 and December 2013. The months between January 2014 and July 2015 belonged to the third phase, the 'interval for the national election and post-election reaction.' The period between October 2015 and November 2016 was the fourth phase, a phase of 'rigorous movement.' In the fifth phase, from December 2016 to March 2017, the movement seemed a little 'slow and mild.' The sixth phase, 'stages of resettlement and reconstitution' comprised the forces that happened (and are happening) from April 2017 to the present time (author's fieldwork February-March 2019, Author's constant observation October 2017-present).

If we consider any social movement as an action seeking specific change which runs for a minimum period, the Sundarban-Rampal Anti Power-Plant Movement activists can be seen as having been through several years of collective resistance from 2012 to the present time. Their demonstrations have used mediums of protest encompassing every known cultural and socio-political expression. In terms of activism, more or less similar statements were made by the 24 interviewees of Dhaka city. For this article; all interviewees were considered representatives of civil intellectuals, as they belonged to the National Committee's common platform with also coming from other environmental activists' organizations, policy-making institutions, and progressive partisans consisting of other independent civil professions in Bangladesh. Common findings regarding the activism process emerged in their conversations during the intensive interviews. All 24 interviewees reported on several protest demonstrations that apparently opposed the government's decision and produced their discourse in contradiction of the scientific rationale given by state authorities responsible for establishing the Rampal power plant.

The six phases of Sundarban-Rampal Anti Power-Plant Movement have been carried out over the past eight years and are demonstrated by arranging public gatherings, protest gatherings, committee meetings, public rallies, protest rallies, news statements for national newspapers, collective statements, 
press releases, human chains, the long march, round-table meetings for the exchange of opinions, protest letters to authorities, conventions, walks of demand, lobbying, innovative applications with ideas like cycle processions and an art exhibition in front of the National Martyrs' Memorial monument, protest road march, transnational protest demonstration, breaking barricades, direct confrontation with the police incurring mass injuries, creating songs, drama, street drama, documentaries, etc., as well as convening national strikes.

In a personal interview in May 2018, Professor Anu Muhammad (62), the member-secretary of the National Committee, stated that:

Now the government had come to the state where it became more aggressive, more determined to establish the plant. Due to the movement, due to the counter-logic derived from our activities, the government stubbornly campaigned for it. Without our resistance, they could sell this initiative as a development revolution in Bangladesh, but they are now making people irritated, agitated. Their hostile obstinate steps will become their liability, even among the supporters in the political party that belongs to the government.

Sultana Kamal (69), a Bangladeshi lawyer and human rights activist engaged to the Sundarban Anti-Rampal protest, provided the following statement on this issue:

At the present moment, the government becomes so stubborn if somebody challenges them. They have an attitude of showing the person how strong they are. But we who come from the civil entities can't make them understand that this kind of destructive initiative is not about showing power. We are not equally placed in the level playing field with the state. The state may hold the maximum power to pursue this, but we, the representatives coming from mainstream civil categories, have been showing our genuine anxiety in a peaceful democratic way.

Dr Md. Abdul Matin (65), General Secretary of Bangladesh Poribesh Andolon (BAPA), a volunteer organization seeking to protect Bangladesh's environment stated that:

The current government continuously argues in favor of the coal-fired plant in Rampal as coal to them is the cheapest ingredient for the production of electricity. But we understand it is one of the most expensive destructive elements that can finish everything through severe pollution. So their argument remains false. Among the 63 BAPA movements, Rampal is one of our major concerns, as this case may bring severe risks to the ecological balance of Bangladesh.

With the alignment of left-leaning political parties, civil organizations, and civil intellectual activists, the National Committee offered an alternative proposal plan for the Rampal power plant. With pointed counter-arguments based on scientific facts and examined by several national and international experts and analysts, this proposal has been published as a comprehensive guideline for the government regarding this plant. As a literary outlet for the movement, a quarterly journal Sharbajankotha ${ }^{18}$ has been regularly published by the intellectual activists who provide discursive facts encompassing regular discussion of the Rampal power plant in every print edition. Moreover, various movements and awareness-building activities, including personal pages on Facebook, independent writing blogs, and websites are being used to present reactions, protests, campaigns, and ongoing information about the Rampal power plant project.

18 A quarterly journal published by intellectual activists who are directly involved in the Sundarban-Rampal Anti Power-Plant Movement Movement. This journal introduces reflective understandings and critical analysis regarding contemporary socio-political issues in Bangladesh, with a special focus on the Sundarban-Rampal Anti Power-Plant Movement and other current social movements. It was initiated as an alternative intellectual attempt of this movement. 
In addition to the 24 civil intellectual activists, the remaining 25 interview participants from Rampal Upazila and Mongla Upazila, Bagerhat, were chosen to provide a holistic understanding and reflection of their voices on the situation. Through the latter interviews, the study gauged the opinions of government representatives and local professionals to explore the nexus of civil intellectual bodies' social connection in this issue. These people were interviewed to avoid the biased self-explanation and justification from the 24 civil intellectuals interviewed regarding their engagement with the movement.

To conduct the research, it was equally important to know the perspectives of government officials who were assigned in those areas' administration. Therefore, an earlier personal communication and association was established before approaching formal interview sessions. In Rampal Upazila, Bagerhat, among the 11 interview participants, four government officials as the state representatives were interviewed who seemed to be politically neutral in answering and went to great lengths to avoid all opinions that were contrary to those of the current government. They provided helpful information and documentation, such as official papers, but agreed to be interviewed only if their name and identity remained confidential.

One executive from the local civil service (32) stated that:

We are experiencing the ecological imbalance and environmental impacts around this area and greater Sundarban, which is very evident as well. Quite often, the activists and leaders of the movement come to us to know my opinion. But I can express which I am allowed to. You see I have my responsibilities and ethical boundaries being an officer of civil service.

In Rampal Upazila, among the other nine interviewees; two were technical professionals who were directly connected to building the power plant site which was heavily restricted and risky for outsiders in many aspects.

Kamruzzaman (41), assigned as one of the technical builders of the Rampal power plant project; was asked about the potential environmental risks bout the Sundarbans. He stated:

I don't think this power plant would destroy the Sundarban at all. This area covers $15 \mathrm{~km}$ in total, which is secured and far from the central forest. The only risk could be the vehicles of carrying fuels that will come across through the river. If it sinks, it will pollute water. Otherwise, it will be ultimately the biggest township in the area and serve local people. I don't know on which ground the movement activists are arguing regarding its adverse effect. Maybe my knowledge is limited.

Interestingly, the other seven local interviewees from different professions clearly expressed their anxiety about the plant, indicating that they thought it was already polluting the river and soil of the adjacent Sundarban area. Although not engaged in the movement, they were well aware of its activities and provided moral support if the movement was really for the sake of saving the Sundarbans.

In Rampal Upazila, three focus group discussions, comprising five to six people in each group, took place among the local people. All three groups agreed on the future adverse ecological effects of the Rampal power plant along with the stress of losing their old professions. Group 1 emphasized issues of the government's power imposition in acquiring land and their helplessness, whereas, Group 2 seemed less bothered by future damage. Group 3 expressed worries about their future displacement and change in their current professions.

In Mongla Upazila, 14 interviews were conducted with state representatives, of which three interviewees' statements were very similar to those of the state officials of Rampal Upazila, Bagerhat. However, as this part of the area was much more integrated and closer to the main part of the Sundarbans, few differences in perspectives were noticed. In this study, it was evident that state representatives were reserved in freely expressing their opinions as they feared the consequences of their discussion. The 11 remaining interviewees were local businessmen, teachers, development workers, journalists, and other professionals. In Mongla Upazila, among these 11; five reported their 
participation in regional meetings and public gatherings held by civil intellectual activists, but they voiced complaints about the effectiveness of the movement process.

Regarding the issue of local people's participation in the movement Suraiya Begum (36), a development worker expressed as:

There is a moral support of local people in this campaign. But as the building of the power plant runs according to its plan and shelving, the movement seems distant in its success. The government will make it with sheer stubbornness wherein protest is also a primary necessity.

The other six interviewees seemed comparatively neutral about the movement, although two, in particular, expressed their anger at the state's sponsored imposition to establish the plant.

Four focus group discussions were conducted, comprising five to eight persons in each group. Groups 1 and 3 raised concerns about displacement and their fear of economic insecurity in the fishing profession. With most group participants engaged in fishing, they suspected less growth and reduced supply of fish and crabs. Group 2 reported the disappearances of the edges of rivers and less wildlife: They were engaged in the business of extracting forest honey, fuel, and forest products. Group 4 reported their concerns about changing from forefathers' occupations. All four groups revealed their lack of awareness about the movement as some only saw the news on television.

However, if critically viewing the data gathered from interview sessions with various professionals at other sites and from participants of focus group discussions, almost every local person in the area is debating the Rampal power plant which is definitely not viewed as a satisfactory symbol of energy development. To them, instead, it is an 'imposed development scheme' by the current government. However, due to inadequate networks and communications and the lack of collectivity among the masses, they have not been able to counter this governmentalization process in a unified way, with the urban civil intellectuals remaining the main actor for delivering the resistance.

It was previously stated that the participation-observation comprised three demonstrations of civil intellectuals witnessed in capital Dhaka; in 2018, throughout the second fieldwork by the author. The open 'public gathering and speech' on 19 April 2018 was on the issue of a sank ship moving across the inland branch 'Passur River' of Sundarbans which seemed to be a big threat to its ecosystem as the ship was carrying coals for the plant construction site. In their protest speeches, the civil activist speakers showed concerns and anxiety regarding these kinds of movements of coal-carrying water vehicles that might create further risks and pollute the water bodies of the forest. The round-table discussion and opinion- exchange theme of 26 April 2018 was on future alternative ideas regarding movement. The necessity of the implementations of forest-friendly laws and associated forest conservation acts and ideas were discussed in this discussion. The urgent meeting of 7 May 2018 was about complaining against a lack of regulation and corruption of the government in issues of energy policies like the Rampal project. It was a meeting announcing the upcoming 'press briefing' program for 12 May 2018, placing the criticisms on state-imposed energy policy activities, contracts and state regulation issued by the National Committee in front of media (Author's second fieldwork, April-May 2018, in Dhaka).

Placed within the Foucaultian idea of discourse, the Sundarban-Rampal Anti Power-Plant Movement conceivably symbolizes the presence of civil intellectuals against the controversial energy policies of the government. They create ideas or patterned ways of thinking about those policies that can be identifiable in their literary, verbal, socio-cultural, and political demonstrations (Lupton 1992, p. 145 [75], cited in Reference [76]) and are undeniably located in the struggle against the power structure. As in Foucault, the discourse may not reveal the universality of meaning, but it brings to light the action of imposed scarcity, with the fundamental power of affirmation (Foucault, cited in Reference [34] (p. 73)). The case of this social movement shows the dual discourse of the government and the civil intellectuals in which they are arguing with their intentions of justifying the logic and counter-logic. The difference may lie in the mechanism of power behaviors which the state is approaching through its 'governmentalistic' outlook towards this so-called neoliberal development that contradicts the major interests of the environment, as well as those of the entire ecology. In these circumstances, 
hiring campaigners and agents is nothing other than part of the action of the power matrix that runs through the system set for a ruling. Foucault addressed this as the "ensemble formed by the various factors that allow the exercise of this very specific albeit complex form of power" (Foucault, cited in Reference [42] (p. 221)). The case of the Sundarban-Rampal Anti Power-Plant Movement also belongs to the counter-hegemonic process, in which the civil intellectuals are found to have the sense of delivering counter-hegemony based on their intellectual language that demystifies ideological reality when directed toward hegemonic governance [77] (pp. 101-102).

\subsection{Civil Intellectuals' Sense of Eco-Nationalistic Ideology: Contradicting the State's Development-Nationalistic Motives?}

This subsection argues that when the state becomes autonomously authoritarian in the implementation of any firm decision that it has made, it correspondingly creates a cultural gap with the ideology of intellectual vocals. Let us suppose that both entities present a sense of nationalism (as they, at least, claim). Therefore, the question is: Precisely on which point do they contradict each other with their ideology? Historically, this has usually been experienced within national agendas with the state functioning through its power approach, whereas, the conscious entities of civil intellectuals went forward through their cultural approach, along with seeing the issues critically and their quest for the state's accountability. The case of the Sundarban-Rampal Anti Power-Plant Movement brings us to the specific aim of seeking to understand the real sense of civil intellectuals' eco-nationalistic ideology which contradicts the government's motives for neoliberal expansion in the name of development and national prosperity.

In the previous subsection, it was slightly assumed that, in a country like Bangladesh, the so-called development approach destroying its natural atmosphere broadens the government's neoliberal ruling tendency as encouraged by other large commercial agencies. Here, using the state's apparatus, power, and art of ruling, the government is doing exactly what it was supposed to do-accelerating foreign market expansion which the pseudo-nationalistic attitude that they represent; also questionable in many respects. According to Marxist elucidation, the understanding of the state has always remained in the "material interpretation of history" - the idea that incorporates the mode of production, with its production relationship equivalent with the notion of the superstructure. To Marx, the state was entirely understood within the profound realization of its economic structure (Oladipo 1991 [78] and Heywood 2007 (p. 94) [79], cited in Reference [80]). Therefore, if neoliberalism is seen as the state's capitalist transformation [81], it might be possible to present a clear understanding of the authoritarian image in the dispute with the Sundarban-Rampal Anti Power-Plant Movement.

However, in this study of the movement, the data from the interviews conducted with 24 civil intellectuals show their keen sense of concerns about the mangrove forest. Some tend to consider this piece of mangrove forest as a national source of wealth, with it also identified as the 'forest mother.' At times, the protest themes for demonstrations have been iconified with the local native species and landscapes of the Sundarbans. Quite often, interviewees and key informants described their emotions relating to the forest and their country. In placards, banners, leaflets, brochures, $t$-shirts, and posters -all the mediums and tools for expressive protests-icons like the tiger, trees, rivers, deer, canals, and the black smoke of the power plant were used to portray a pictorial message to communicate with the public.

The three posters in Figure 3 iconify and portray the wildlife and habitats of the Sundarbans to show the potential disaster of establishing the Rampal coal-fired power plant. These posters show the possible effects that were manifested on posters and banners during the movement's activities. 


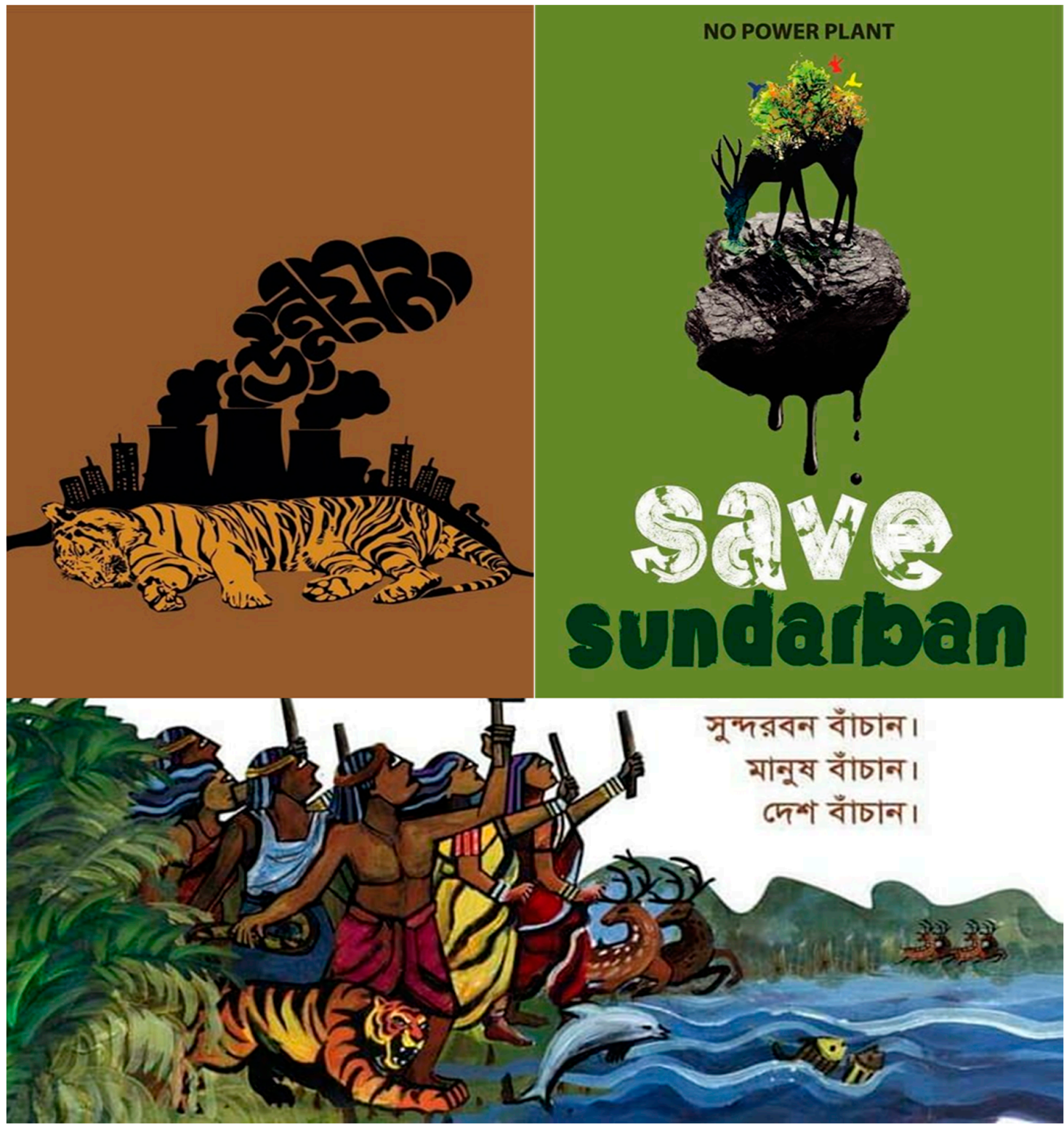

Figure 3. Posters used in Sundarban Anti-Rampal Movement (Source: Reference [82]).

As can be seen in a video collected during fieldwork, in one street demonstration, some activists were singing, coining a slogan that said "freedom doesn't mean to be [a] slave of coal or nuclear power generated electricity." The song was as follows:

O passerby, rise and break the barricade, destroy all the risks for the mangrove.

We will pick up the strong axes.

Oh mother, we won't let the Sundarbans be destroyed.

Go back India. Go back Russia ${ }^{19}$ (Translated from Bengali)

19 This wording refers to the attempt to build the Rooppur Nuclear Power Plant which is a 2.4 gigawatt electrical output (GWe) plant under construction in Bangladesh. It is being constructed at the Ishwardi Upazila in the Pabna District of Bangladesh on the bank of the River Padma. Due to fear of the weak and fragile maintenance system of this nuclear power plant, intellectual activists are also opposing the Russian Rosatom State Atomic Energy Corporation that is responsible for financing the plant. 
To reply towards the emotional integration with the movement, the educator, writer, and activist, Mushahida Sultana (39), Associate Professor, Dhaka University, stated:

I don't see this Sundarban Anti-Rampal movement as a separate problem issue in comparison to the other problems of injustice and inequality issues of the masses of Bangladesh. Though people don't tend to respond to its immediate effects, they will still suffer as the government is buying the lands and placing the intruders in this Southern zone near the forest area. To me, the Sundarbans are like part of this country, and we can't allow them to dominate this land so easily in the name of development and business expansion. To me, the forest is like saving a mother.

Kafil Ahmed (54), poet, singer and convener of the cultural organization called Shorbojaan Shangshkritik Parishad (The Cultural Organization for Every Living Thing) stated that:

When we visited the areas of the Sundarbans during the movement, we heard the local people addressing the royal Bengal tiger as Boromama (Big Uncle in the Bengali language) as it is the protector of the forest. The forest is called Bonbibi (Queen Forest), as she is believed as their savior. We also believe in the jungle as part of our mother nation.

The narrative of the 'nation as mother' was criticized by Reference [83] as a 'trapped' notion of the colonial knowledge of power with its status focused on derivative discourse. Chatterjee (cited in Reference [83]) also marked this tendency to be extracted from the gallery of given 'models' by the West. However, the current study tries not to be judgmental for certain contexts as, at times, it is more critical to adopt a conscious emotional approach to combat the born supremacy of power for the sake of the interests of the masses. In employing idiosyncratic terms, Foucault also analyzed the civil entities who distinguished themselves in the matter of their political subjugation and their 'sense of docileness' to the state, tending to appear as a distinct unit ([84], or as a 'subversive agent' whose existence is connected to the making of contextual truth, with this being definitely through political understanding ([85] (pp. 135-137). Perhaps Foucault expected civil intellectuals to demonstrate political correctness in their expression.

The general patriotic thinking and the notion of nationalism emerged from the other 25 interviewees during the focus group discussions in Rampal Upazila and Mongla Upazila, Bagerhat, regarding the issue of establishing the Rampal power plant. It was observed that regarding the issues on present government's motive, the government officials responded neutrally and did not express any sense of urgency about the plant's side effects and alternative plans of the current government. Most interviewees revealed they did not have enough knowledge about the movement's eco-nationalistic features nor about its philosophy, internal politics, etc. However, they indicated they felt assured about the movement's positive outlook and the civil intellectuals' activities.

Iftekhar Hussain (33), a local businessman, stated that:

As a whole, this movement is a good initiative for saving the forest. The forest Sundarbans protect us from the various cyclones and tornados. One thing we understand that we have to conserve the forest. Otherwise, this south area will face severe damages in the future as we have the sea Bay of Bengal there. We depend on the eco-system. So if we love our land, we have to save its belongings as well.

During the three focus group discussions conducted in Rampal Upazila, all three groups agreed on the presence of activism and supported its aim. Their general statement, paraphrased below, was:

We heard that some people in Dhaka city are concerned about the problem of the power plant. It is a positive sign that what we can't say in the literary language they are speaking it on behalf of us. We only want to assure our sustainability. But we also fear that if the movement doesn't get successful finally, what will be the fate of our future. Will they take care of us at that time? 
The four focus group discussions held in Mongla Upazila emphasized group participants' innate understanding as they live very near to the main forest. Sadhu Da (58), one of the participants of Group 3, stated:

We live our life here for many years and probably centuries. Even our father, grandfather, their forefathers used to live here, within this area. We measure environmental changes putting our fingers in the river water. Its warmth, tide and flow teach us naturally. We remained happy so far, and we want the balance of the land intact, as it always was. Sudden development brings sudden change that may be intolerable.

As the current study observed, the Sundarban-Rampal Anti Power-Plant Movement was mostly an urban social movement. However, the issues of consistent collectiveness and network efficiency of civil intellectuals among local people were in significant need. From the focus group discussions, statements clearly expressed local people's sense of insecurity and confusion about the movement's effectiveness and the extent of civil intellectuals' future responsibility.

The Bangladesh government denies the accusations of adverse effects, with the energy adviser to the Bangladeshi Prime Minister stating that the expressed risks for the Sundarbans are "not based on facts" and that "the mitigation measures will be taken care of according to the environmental assessment" [86]. During fieldwork for this study, it was observed that the construction process was going very smoothly, confirmed by all the strict security at the site. This was addressed by Reference [51] as "the way of governing nature" that focuses on how the government makes decisions to manage the areas and spaces and sets conditions paving the way for implementing their intentions. Predictably, these statements are not seen as acceptable to activists and environmentalists who have, so far, provided an enormous amount of scientific facts. Therefore, to date, a clear distinction has been drawn between the actors regarding the justification for establishing this damaging coal-fired power plant on the edge of the world's biggest mangrove forest.

This study assesses that between these two contradicting senses of nationalist narratives offered by civil intellectuals and the government; make political disputes and debates those are to be more explored. In this process; both sides are making their rationales for people to pursue their own arguments, either through building abstract image of 'earth-mother-country' by intellectuals or image of 'immediate and drastic development' by the government itself. In author's understanding, both portrayed images are equally important to identify their creative ways of communication strategy for people. It probably helps in realizing the different actors of the state and their political psyche in terms of power mechanism.

\subsection{Civil Intellectuals: Their Understanding of Adamant Eco-Governance}

Continuing from the previous point, this subsection argues that the Sundarban-Rampal Anti Power-Plant Movement signifies not only eco-nationalistic motivation, but also recognizes civil intellectuals' concerns that oppose the stubborn tendency of the government regarding eco-governance. This subsection also seeks the answer to historical interests, including the difference between political struggle and issues of political ecology in the context of Bangladesh.

Capturing the environment and placing it into neoliberal development projects seems to be an extensive process within the capitalist mode of ruling the world's economic expansion. The discussion was affirmed by Reference [87], shows the empirical relationship between environmental degradation and economic development in the world's systems. Marxist environmentalists often argue about the deep bond between neoliberal expansion and ecological hazards. Indeed, in the current study, the question asked is how economic expansion and its profit-making intention distinguish governance within an obstinate position in a specific context. According to Foucault, neoliberal governmentality consists of a set of mechanisms and technologies to obtain specific effects [88]. The case of the mangrove forest, the Sundarbans, is a notable example of eco-governance in several respects. This is framed within concerns about understanding its association from the perspectives of political ecology and its 
controversies. In previous statements, the National Committee suspected India's motives, as well as the uneven diplomacy between the two countries of Bangladesh and India. The activists' group already termed this situation as "disastrous black businesses" in their previous arguments. The group, when protesting against open-pit coal mining in Phulbari in 2006, presented one of the militant expressions of resistance in the history of social movements in Bangladesh. In these circumstances, establishing this coal-fired power plant is inevitably seen as a threat to the mangrove forest, the Sundarbans, with its associated local areas for native habitats.

Activist and international relationship analyst, Professor Tanzim Uddin Khan (59), Dhaka University, identified the position of the government and the Rampal power plant as follows:

If we observe politically, the present people in power don't require votes any more or don't remain in the practice of healthy democracy. Thus, when they face some existential crisis in legitimacy, they tend to take some massive development projects through, depending on external economic and political forces. So establishing this kind of thermal plant might be the chance to give spaces to India for further commercial expansion. I might be wrong, but it does have a strategic significance in the diplomatic relationship.

During the year of fieldwork, it was observed that establishing the thermal power station was not the only means for the project. With several types of machinery businesses and small factories for supplying associated materials, the whole area is currently crowded with the presence of foreign investors, people in business, workers, and associates in running the businesses.

Of the 25 interview participants in Rampal and Mongla Upazilas, Bagerhat, except for government officials, the rest reported their awareness about the business deal between Bangladesh and India to establish the power plant. Regarding the issue of eco-governance, their main suspicion, interest, and inquiry were, 'why was this area so close to the Sundarbans chosen for the power plant?' Many also mentioned that they knew about the low-grade coal to be used as fuel to run the plant. They were also suspicious of the plant authority's promise to offer jobs in the plant to local people.

This study found the local iron businessman Rois Miah (42), in some confusion about the situation. As he states:

The people engaged in the plant and machinery business give us constant assurance that we will get jobs in the power plant so it will help the jobless people in earning money. But I often think about how many people will be hired in the plant where it has a limited capacity. So if our local business is taken over by foreign entrepreneurs, I don't know what will ultimately happen to me and my next generations. Sorry, I don't have the answer.

Participants in the seven focus groups in Rampal and Mongla Upazilas were not aware of political issues between the two countries. However, as they knew about situations in the border areas near the Sundarbans, they discussed their indigenous understanding of ecological affairs and current changes.

The observed 'round-table discussion and opinion-exchange' by National Committee on 26 April 2018 emphasized the future risks of these disastrous kinds of power plants in Bangladesh, including Rampal coal-fired plant and Rooppur Nuclear Power Plant ${ }^{20}$ and foreign interest of other countries like India and Russia. In the session, it was argued that in this energy transactions, Bangladesh would be the only worst victim in terms of possible loss (Author's fieldwork April-May 2018).

Amid this tension, one critical inquiry refers to the absence of a satisfactory history of the struggle for the environmental movement in the past in Bangladesh. After the Liberation War of 1971, the pathway to adequate democracy was always the requirement for national politics. Fragmented

20 A nuclear power plant being built by Russian Rosatom State Atomic Energy Corporation in Pabna District, Bangladesh. Civil Intellectuals of the National Committee believes this to be another disastrous power plant scheme like Rampal Coal-Fired Power Plant; if fails in operation in future. 
movements occurred in some collective ways, but threats to the main forest of the Sundarbans were perhaps a unique experience of ecological anxiety that the people of Bangladesh were facing for the very first time. Perhaps this also gives the movement a unique character. By this time, several Indian experts had expressed doubts about how the Bangladesh government had even approved the Rampal power plant in the first place, with it being located near a vulnerable environment site like the Sundarbans [89].

It is evident in the present situation that the engagement of the masses in this complex power affair is not very visible. The current study considers this tendency as "remaining mutely docile to the rationality of government." It is an undeniable fact; if seen from the perspective of the authorities, while they took the opportunity to select the location in Rampal Upazila for the plant, due to the barrenness of its acres and acres of land. Justifying this situational fact, Baki Billah (39), writer, journalist and activist, and designated member of a political party stated in the interview that:

My hometown is Rampal, which is very close to the Sundarbans. I memorized the childhood when we used to go to my uncle's house by boats. I can't match this scenario after 25 years of my life. That time, the present barren land was useful for producing rice. Once in a year, the salt used to go away from the ground. But gradually, the local people started doing shrimp cultivation, and it made the land unusable now. The government of Bangladesh took this chance to take over mile after mile as it became utterly barren land due to the lack of land utility with alkaline soil. Local people are less bothered about this plant area now. Moreover, we have had autocratic political domination for years and unorganized movement techniques. That is why we couldn't engage the masses up to our expectations.

Being involved in the Rampal power plant controversy, even the country, India had such environmental movements, such as the Chipco Movements, Normoda Bachao Andolon and other mentionable resistance. In the case of the Sundarban-Rampal Anti Power-Plant Movement, the situation is part of the complex mechanism of the Bangladesh government's imposed ecological rationality that has been used to normalize the way that the power plant is being established. In this situation, it may not be necessary to exercise power in the brutal process, as the state has supreme access to every element of governance, thus, making it easier, despite protests and resistance by civil intellectuals and the masses.

\subsection{Civil Intellectuals' Involvement with Affected Local People: Towards their Functional Limitations}

This subsection focuses on the significance of the functional limitations of civil intellectual activism. In this regard, it argues that, in the organization process of the Sundarban-Rampal Anti Power-Plant Movement, the civil intellectuals were comparatively weak in dealing with the process of engaging the local native people with the movement. Before continuing with this point, it is important to be clear about one thing in this case of a specific movement. For this article, the coined term 'civil intellectuals' is considered as the category who are seen as absolute assimilated entities, including every notion of intellectuals discussed academically to date (e.g., traditional intellectuals, organic intellectuals, public intellectuals, etc.).

While interpreting The Prison Notebooks, Reference [54] (pp. 131-145) represents Antonio Gramsci's complex idea of 'intellectuals', illustrating them as 'functionaries' who can be measured within their 'organic quality' reflecting on various social strata and the degree of social connections. Although in Gramsci's elaboration, "civil society as private" and "political society as the state" are found in the levels of the superstructure, the current study intentionally uses the term like 'civil intellectuals' as, in this case, they represent a different facet in this case of intellectual resistance. In his writings, Foucault advocated for a type of intellectual, namely, 'specific intellectuals' [60], (pp. 126-133); where References [90,91] addressed them as entities who 'demand the expansion of rights' or 'demand specific rights' which are to be respected within a particular context. Discussing the effectiveness of intellectuals in the power struggle, Reference [92] explained Foucault's idea as 'engaged intellectuals,' 'critical 
intellectuals,' or 'specific intellectuals' [90] who can test their discourse against their awareness of the dominant regime through the weapon of knowledge to become functional in the struggle. Therefore, in this engagement, the question for them is: How is the capacity of becoming 'engaged' or 'critical' or 'specific' developed in the intelligent nature, while combatting the ruling discourse and ideological war? What demonstrates activism in living when they are called for engagement in a given situation, such as social movements? If they function, what are the limitations of the question of collectiveness? This subsection discusses their functional limitations with respect to connectivity to the locally affected as subaltern people.

What is entirely unquestionable is that in the Sundarban-Rampal Anti Power-Plant Movement, the soul agent; the masses- who are addressed here as the 'subalterns,' the 'affected' or the 'witnesses' and are less engaged in the movement process. This might have several reasons. However, undoubtedly, the lower number involved affects the collective strength in the movement, which signifies the inefficiency of civil intellectual activists in its foundation.

Baki Billah (39), writer, journalist and activist, and designated member of a political party affirmed this issue as:

People of [the] Rampal area realize the problem but, in my understanding, it's still not an immediate emergency for them. As we continuously measure the data and scientific facts that are harmful to the ecological balance, we can imagine how it will be. But for a local person, maybe it's not a problem where the direct effect is still too far [away] and not closely observable. So without having a continuous organic connection, there is no valid reason for sudden revolt. For the last 20 years, the people of this area have witnessed many sorts of degradation of the environment, so any sudden change may not be listed in their mental mapping either. On the question of success, this movement is culturally successful in many aspects but couldn't meet up with the political demand in its organizational process as the National Committee was the politically led platform along with intellectual activists. It holds a character of urban movement too.

Regarding the constraints of civil intellectuals' functional limitations, this topic produced the most answers in common, even among the other 25 interviewees and participants in the seven focus groups. In terms of the integrity and engagement of civil intellectuals on any given social problem, the state representatives expressed severe frustrations. To them, "what we understand by civil society and intellectuals is still very weak, due to their fragmented political behavior with respect to Bangladesh". One state executive commented that, "it needs the courage to stand for truth." After receiving reassurance and hearing of the National Committee's activity, he asked, "but who will hold until the last situation?" The other 18 interview participants reported some important points. The participants mentioned that the government could acquire the land easily as this land, without crop productivity, was regarded as barren. Thus, to these participants, the need for resistance was not felt so strongly, due to the barrenness of the land.

Moreover, oppressive interference and business deals by local authorities also made the land accessible to the government. The participants also pointed out the organizational failure of the local progressive political parties. Besides, they mentioned about the government's constant development campaigns regarding hiring local people in the power plant and its adjacent township.

However, the current study has shown how this pseudo-development could be the cause of future displacement and the denial of indigenous culture. Many participants in the seven focus group discussions, in mentioning a particular word that means "natural wisdom and gut feeling," suggested that this power plant was not for the welfare of the people of southern Bangladesh. In their language, participants felt that their position was between "not supporting entirely" and "not opposing, due to having a lack of knowledge and strength."

According to the fieldwork observation, the questions on the inefficiency of civil intellectuals in engaging local people encompassed five important rationales: (a) Pattern of discourse language during 
communication; (b) internal tensions and different opinions among group entities; (c) representation in a messianic role; (d) suppressive interruptions by local authorities; and (e) a constant campaigning of government about opportunities of this development that weakens necessity of resistance.

In this case, the lag between local people and civil intellectuals was observed in terms of the language during communication. Naturally, the activists' group approached with their scientific rationality and discursive factual information which the local people used to comprehend and interpret according to their understanding of the problem. Therefore, the "functionality of communicative dialogue" seemed to be a major constraint in this situation. Moreover, it must be considered that most of the 'civil intellectuals' were from Dhaka city. Many were not well accustomed to the culture of the local inhabitants unless they had some organizational training in terms of knowing and applying the systematic movement procedure. For the reader's understanding of this article, this gap may lead to alienation and cultural elitism, which could make the movement dysfunctional if the limitation is not taken seriously.

As Gias Uddin (60), a fisherman also engaged in crab cultivation, and from the local village of Sundarban stated:

We don't have significant scientific knowledge. All we understand is the amount of fish in the river, the temperature of the water, and coastal risks for our livelihood. I heard the leaders came here, but I couldn't meet them. I understand by my own experience from changes in nature.

Through the intensive interviews, a certain degree of internal tensions and different opinions were felt between the group entities of the civil intellectual activists. As the platform consisted of various functionaries coming from different disciplines, as well as public engagements- ideological instability was present in the function for movement activities.

Anis Rayhan (34), a writer, journalist, political organizer, and movement activist, affirmed that:

I see this problem of internal tensions belongs to the movement into three spheres. Firstly, I assume that there were ideological differences between activist intellectuals and political leaders; where secondly there were groups who came from the pro-government section too-who used to have the concern of how the current government will accept their position and thirdly, there were clashes of opinions between core intellectuals and core organic activists. Many of them were seen calming the importance of their views.

To some extent, it is arguable that, somehow, the entities of the civil intellectual activists portrayed a messianic role in the organizing and leadership of the movement. Still, the Sundarban-Rampal Anti Power-Plant Movement, with its feature of a top-down tendency in its function, achieved the voices of the local people less. Furthermore, Reference [56], in highlighting the exact point made by Reference [55], picked the subaltern issue, which confirmed the establishment of their explanation that answered the question of recognizing subalterns' existent voices, and not hiding the presence of their actuality.

The fourth reason implied the suppressive interruptions of the local authority that comprised the local agents of the government. Similar findings were also evident in Reference [93]'s relevant study in which these authors showed that the ruling party appeared to be very powerful both socially and politically in the area. In this study, the interviewees reported that, during public demonstrations, they made trouble and created hazards so the activists could not function appropriately in public gatherings. It was also reported that the acting representatives of the local police station and the authorities did not approach to help things run smoothly during programs. Furthermore, when collecting data around the Rampal power plant site, several spies and suspects had been observed by the author, herself; who were inquiring about any strangers who were interested in seeing the activities inside the area of the power plant. The fifth rationale would refer to the constant campaign of government authorities who are working hard to prove their statement in the area. 
On the same day of 26 April 2018 in capital Dhaka, during the round-table and opinion-exchange session, the issues on communicative language that connects local people more in the movement; were well discussed and felt like a functional limitation by speakers themselves.

There are scopes to understand the problems in dealing with the 'subalterns' with the notion of Foucault's 'subjugated knowledge' which refers to the emergence of the insidious imbalance of power. This is not always seen with an oppressive intention, but it indicates the existence of 'privileged truth' [94]. This point shows, in the profound power mechanism, knowledge can appear as subjugated or shadowed by the advantaged or privileged entities; either spokespersons from the state or civil intellectuals. Whoever the advantaged identities are, in the case of the Sundarban-Rampal Anti Power-Plant Movement, the general people tended to be affected without having recognition of their own opinions as well.

\subsection{Civil Intellectuals in the Discourse for the Movement: A Concoction of Assembled Existences}

This final subsection seeks to recognize civil intellectual activists in a new formation of a political and cultural sense concoction that produces counter-hegemony. This ultimately helps to modify the nature of civil intellectual activists in protest issues in the context of Bangladesh. It also seeks an answer to the following question: Do the civil intellectuals show any new organic path to a unique social change for the masses, which is different from traditional behavior? On this point, it assumes that civil intellectuals are a political entity that can be measured only through conscious reflection.

In the Sundarban-Rampal Anti Power-Plant Movement, several intellectual individuals who joined the movement's platform are combined and understood by the term 'civil intellectuals' that extracts ideas from both 'civil entities' and 'intellectuals.' Through creating this blend, the current study aimed to place them in the newly emerging forms of political and cultural unique entity concoction, due to their diversified expressions of cultural existence and existential enlightenment, as were certainly manifested in protest issues. The 24 civil intellectual interviewees in Dhaka city comprised educators in public universities, an independent intellectual, journalists, investigative researchers, environmentalists, activist lawyers, cultural activists, a poet and singer, and progressive politicians-with every single one directly connected to the National Committee platform and working with its alliances. Most importantly, all 24 interviewees were contributing to the intellectual thinking process in different domains of social justice issues. At the same time, they were in the urban sphere, with active concerns for various national problems. On this basis, for the current study, they were identified as symbols of the civil intelligentsia in the context of Bangladesh. In the relevance of an Enlighten being, Immanuel Kant's direct statement seems to be suitable as it says about a sense of courage which must be used for a being's understanding [95], whereas, the somewhat contrary Foucauldian position emphasized on "being born inquisitive" [96]. Although the arguments here dealt with the presence of civil intellectuals in the reality of political and cultural sense, this attempt certainly examined them in a performative framework [97], namely, the social movement of the Sundarban-Rampal Anti Power-Plant Movement. For this specific case, no opportunity presented itself to deny that any single entity was not "intellectually active."

Consequently, the questions emerged again about what is 'intellectuality' and why this article is referring to them as 'intellectuals?' For this article, intellectuality means 'conscious activeness' in the context of raising a protest. In addition, it includes 'civil entities' through to intellectuality, due to the urban movement character of the Sundarban-Rampal Anti Power-Plant Movement that was previously explained with data.

As previously stated as a tool for reflection, an extra 25 interviews and seven focus group discussions took place in areas adjacent to the Sundarbans, namely, Rampal and Mongla Upazilas in Bagerhat district, as well as with civil intellectuals in Dhaka city. In addition to collecting the opinions of people near the Sundarbans and the power plant, these methods also aimed to gain their perspectives on urban civil intellectuals, their actions, and their influence. This might be an effective medium to assess the impacts of their activism in socio-environmental justice issues. In this debate, it 
is obvious that defining civil intellectuals in their role within the social movement itself is the greatest challenge as it connects their interests to the socio-cultural and political mechanisms. In their general statements, many of the 24 intellectual activists identified themselves as 'a conscious being' or 'a conscious activist'. From the focus group discussions, the local people portrayed 'civil intellectuals' with a straightforward unilinear understanding. For the local people, civil intellectuals work as a cluster of individuals who are not like them; as they believe that these individuals live in large cities where they practice knowledge and wisdom, and write and talk publicly. The local (subaltern) people continue to believe that the civil intellectuals stand on their side, that they express views in favor of them and that they are, of course, heroes with patriotic thinking who seek to combat social injustice.

If discourse provides a way to think about the culture of power, then bodies of civil intellectuals are active in providing mental and cultural labor based on their capability of gathering relevant information and knowledge. In reality, in a movement platform, not everybody acts with expertise for every matter but, together, a cluster; those are opposing authoritarian governance may be reflected in their joint quest seeking expected social change for the masses. For the current case of the Sundarban-Rampal Anti Power-Plant Movement, among the identified civil intellectual entities, assimilation of cultural categories is apparent which does not follow the previously set notions for identifying traditional, organic, public, etc. in specific definitions. These intellectual characters, at times, seem to appear with an overlapping role. Sometimes, instead of opposing supremacy in power relations, they are also present in an increasingly broadened, diverse [98], and traversed shape that determines their conscious activities as well.

Gramsci understood the term 'civil society' as an expression of hegemony, a pattern of the established power relations holder among social groups in a historical-political situation [99] but, correspondingly as [61] showed in a critique for Gramsci, as civil society is not as stagnant as it seems. Distantly related, the current article shows how civil professionals move to the deep core of conscious intellectual activities if they are needed for the situation to bring change. Thus, the Sundarban- Rampal Anti Power-Plant Movement even involved many environmentalist non-governmental organizations (NGOs) of Bangladesh along with foreign volunteers worldwide for its campaign and scaling- up the speed of the movement in global platform; possibly with strategic intentions, which became a part of the resistance, at least in the cultural campaigning and its demonstration. In this continuation, this journey included even the global protests ${ }^{21}$ that were held in various places all around the world. Hence, at the present time, the idea of isolating any categories with their previous natures continues to be somewhat dynamic. It is perhaps the time to conduct a more profound exploration more following the changing behaviors of entities, as well as the pattern of movements. Whatever the combination, the discourses of power and political action have been the vital factors for analyzing these kinds of debates.

The shift in the paradigms of the past conventional story of social movements was shown by Reference [100], even emphasized on "multiple social positions." For the case of the Sundarbans, representatives in the movement came from multifunctional and multidimensional organizations, such as the National Committee for Saving the Sundarbans (NCSS, the 'National Committee'); the Bangladesh Environmental Lawyers Association (BELA); Poribesh Bachao Andolon (POBA) (or Save the

21 For saving the mangrove forest Sundarbans, the NCBD called for a global protest that occurred on January 7, 2017 Public gatherings and protest demonstrations in New York of United States, Germany, Netherlands and Australia took place along with Bangladesh. Several Environmental organizations and foreign volunteers, people from alliance groups campaigned for saving the forest from the disastrous effects of the Sundarban-Rampal Power Plant. Organizations like Friends of Earth (US), Ecology Movement Platform, Progressive Forum and Bangladesh Environment Network (BEN) participated on that day (Please see Bangla. Protest for the Sundarbans Will be Held Tomorrow, 6 January 2017. Retrieved from https://www.cp.bangla.report/post/2215- (Accessed on 18 January 2020). Even on October 18, 2016, some social and civil society activists from 'Narmada Bachao Andolan's' National Alliance of People's Movements approached with an "open letter" to the present Indian Prime Minister Narendra Modi in New Delhi; India. In their letter, the civil society members appealed to the Indian Prime Minister to withdraw support for the plant mentioning the irreparable damage to the Sundarbans in Bangladesh [The Daily Star. Rampal Power Plant: Protest In India Too. 19 October 2016. Retrieved from https://www.thedailystar.net/backpage/rampal-power-plant-protest-india-too-1300690. (Accessed on 20 January 2020)]. 
Environment Movement [SEM]); Bangladesh Poribesh Andolon (BAPA) (or the Bangladesh Environmental Movement [BEM]); Bam Morcha (BM); Moulik Bangla (MB); various independent intellectual activists; along with the National Committee that represented the unconventional stance. If we argue that, in the context of Bangladesh, this portrays nothing other than one-optioned counter-hegemony, then that is so. In mentioning the struggle of the National Committee against the past neoliberal governance tendency of the state, Reference [11] accepted all the limitations and realities. It is claimed here that the data and observation could not find options other than this platform that is actively running this movement. In this regard, the activists seemed to have tendencies to protest against political hegemony along with raising other national and eco-political concerns, but they functioned with significant drawbacks. In these circumstances, this research seeks to learn the extent to which they have the potential to go further and act more organically to achieve sustainable change through the movement.

Explained by Reference [101] (pp. 168-169), the cultural analysis of development becomes the state of mind, along with its difficulty of being institutionalized in society; that becomes nearly impossible to exorcise. It appears as a form of rationality and begins to cannibalize optional forms of social interventions. It might be added that these rationales are ultimately given by the supreme authority without any concerns for a destructive outcome. Therefore, what can be done to achieve a well-accepted sense of liberty that all people can enjoy without getting interrupted in their sovereign setting? In the Sundarban case, do the civil intellectuals show any new organic paths or do they practice the same caged attributes generated from their former historical political tradition of antagonizing supremacy? This article would like to say they are performing both. On the one hand, they are active in criticizing governmentality tendency, with this development of organic behavior for future resistance: On the other hand, their flaws also continue about their strategic limitations in the organizational process. This article assumes that they still have the inadequate philosophical strength to become organic to understand their existence and role in the nation-building sense. In The Prison Notebooks, Gramsci used the term "praxis" or "practice" instead of "political action" [77]. Perhaps the next stages for the whole intelligentsia to solve the constraints of 'theory' could be based again on this "praxis". Thus, despite all the debates, an intellectual can be best understood by its' political behavior yet, in other words, "an intellectual is a political being" can be measured only through the process of its' philosophical and cultural reflection.

In this article, the next point leads to the 'discussion' based on the fieldwork results of five significance belonging to the main proposition.

\section{Questioning State-Sponsored Imposition: Civil Intellectuals' Eco-Nationalistic Mode of Activism and Its Significance for the Sundarban-Rampal Anti Power Plant Movement- the Discussion}

The rudimentary concept for this article was the activism of civil intellectuals in the specific case of a social movement, the Sundarban-Rampal Anti Power-Plant Movement, opposing the Bangladesh government's decision to establish a coal-fired power plant at the edge of the world's largest mangrove forest, the Sundarbans. The movement began in 2012 in Bangladesh, in areas of the capital Dhaka city and its southern zone. It has become a unique platform through blending categories of intellectuals through combining civil entities that became the main force in dissenting this state-sponsored political imposition. Based on the theoretical concept of Michel Foucault's 'discourse'- 'governmentality,'-'eco-governance' along with encompassing Antonio Gramsci's 'hegemony'-'counter-hegemony and 'intellectuals'; the study's key proposition argues that civil intellectual entities play a 'counteracting' vital role in contradicting governmental dominance, and within their own fundamental limitations. Under this statement, five points of significance were adopted for verifying the proposition.

\subsection{Civil Intellectuals in Social Action: Discourses and Response to Governmentality}

This first point of significance within the fundamental proposition illustrates the process of activism and includes the six-movement phases demonstrated by civil intellectuals which generate 
counter-discourses that actively express dissents towards the state dominance. Based on the selection and interviews of 24 intellectual individuals, the study findings show how the National Committee's common platform along with its intellectual activist allies has been engaged in a conscious intellectual struggle for this movement. In past decades, civil intellectuals played the role of counter-hegemonic discourse spokespersons to combat the excessive neoliberal tendencies of the country's economy. The study also discusses the attributes of individuals from the intelligentsia within the movement, with these attributes signifying their literary and field-level activism through various socio-cultural demonstrations. This subsection presents data of the other 25 interviewees, their reflections, their activism, and the government's dominant stand, comprising discussions from seven focus groups in two affected areas adjacent to the Sundarbans. From 49 interviews and seven focus group discussions, the finding was that almost every individual confirmed the presence of the state's practical imposition regarding the establishment of the power plant. This point of significance indicates civil intellectuals' counter-discourse process in which they generate their intellectual hegemony in contradiction of the government's rationale and statements. In the current study, these civil intellectuals were found to be the only proactive counter actors running this movement without any other satisfactory alternative agent.

\subsection{Civil Intellectuals' Sense of Eco-Nationalistic Ideology: Contradicting the State's Development-Nationalistic Motives?}

In the second point of significance of the proposition, the data and observations present the view that civil intellectuals' motivation of eco-nationalistic ideology actively contradicts the state's nationalistic motives which have been rationalized in the name of development. The current article addresses the state's psychology, and it's so-called development-nationalistic motives. It discusses the narrative and civil intellectuals' concept of the 'nation as mother' which has received criticism as a 'trapped' essentializing project arising from the colonial knowledge of power by which they have been highly influenced. The study also sought to gather reflections and views of the other 25 interviewees and local people (subalterns) who participated in focus group discussions. The indigenous understanding of the ecological balance that is connected to subalterns' notion of owning territory is also emphasized.

\subsection{Civil Intellectuals: Their Understanding of Adamant Eco-Governance}

For the third point of significance discussed in this subsection, the data and observations represent civil intellectuals' concerns about the associated eco-political affairs in seeking to uncover the reality of diplomatic relations between the two countries, Bangladesh and India. This point also indicates the adamant position of the government that practices a type of eco-governance, with this manifested in the power mechanism that eventually leads to eco-dominance. During fieldwork, the study observed the rapid growth of the market and machinery production in the sites that offer a playground for businesses for further neoliberal expansion in the southern zone of Bangladesh. The study attempted to understand how civil intellectuals realize the tendency of eco-governance while the present authorities hold an obstinate attitude. To achieve this aim, the study tried to extract opinions from the remaining interviewees and focus group participants from Rampal and Mongla Upazilas, but this did not uncover an adequate understanding of the local people regarding the Rampal power plant authority's eco-political motives.

\subsection{Civil Intellectuals' Involvement with Affected Local People: Towards their Functional Limitations}

The fourth point of significance detects the functional limitations of civil intellectuals. Moreover, it confirms the five specific constraints in their organizational failure to engage local (subaltern) people in the nearby area. It identifies the following factors as being responsible for the problems derived from the patterns of discourse, as shown in their language during communication, internal tensions, and different opinions between group entities: The problem of playing a messianic role; suppressive interruptions by local authorities; and the government's constant development campaigning regarding 
the establishment of the power plant. In this finding, the study includes the opinions of local people that revealed the reason for the accessibility of land acquired by the government. This discussion slightly emphasized Foucault's notion of the 'subjugated truth' belonging to the people (subalterns) whose suppressed sense had become overshadowed by the interruption of the 'privileged truth' by both hegemonic bodies, the government and perhaps the civil intellectuals.

\subsection{Civil Intellectuals in the Discourse for the Movement: A Concoction of Assembled Existences}

The fifth point of significance, discussed in the result and discussion subsection, attempts to place civil intellectuals as a concoction of assembled entities who appear to be a necessity in questions about both success and failure. This study recognized them as 'political beings' whose presence can be assured and measured by reflective behaviors among their social connections and networks to the masses by political action, and through 'praxis.' The selected civil intellectual interviewees are assumed as entities which belong to a blended mixture of activism. At the same time their functions performing in the Sundarban-Rampal Anti Power-Plant Movement, are seen as conscious identities of progressiveness questioning their capacity to provide more organic behavior, as they also do things from privileged culturists traditional elitism. This subsection also discussed the general perspectives of the people regarding their existence. This study has the scope to present the detection of these features and particularly of the following two: (a) The contextual tendency of civil intellectuals in terms of protest through social movements; and (b) the uniqueness of the Sundarban-Rampal Anti Power-Plant Movement.

\section{Conclusions}

According to Reference [102], any case of local environmental movement becomes important, due to its organic bond with the global environmental movement concerns. Moreover, the recent global persistent sensitivity regarding issues for the economic crisis and natural resource mobilization; are giving the movements-uprisings the extraordinary features which are distinctive from the movements that happened in the last century. The regional case like Sundarbans-Rampal Anti Power Plant movement, has become unique because it not only brings the simple national resource issue, but also places crucial geo-political concerns and future potential ecological threats. It connects the progressive portion of civil intellectuals of Bangladesh who is struggling the intimidation by the government. Through the resistance they tend to promote an ecological and cultural nationalistic consciousness which even led them to make a 'national strike' for eight hours as a protest demonstration [103], just to save the forest. It has become a movement consisting of multidimensional features that can pave new answers for old existing questions regarding national democracy and regional politics. However, observing the case; helps to understand the dialectical condition of power in the society, as well as to find out the positive and critical perspectives for the studied civil intellectuals. The positive perspective can lead researchers to the detailed formation to further the understanding of the present features of the country's intelligentsia. Similarly, the critical basis may indicate weaknesses in detecting the voices that are active in the unjust social situation. Through analyzing the story of the movement, someone may imagine the contextual condition of the state, power, and its field of concentrations and classifications along with the art of governance (morally legitimate or illegitimate). For this case, with the engagement of intelligent ideas and discourses, a significant cluster of civil intellectuals is found in the power struggle in society. Owing to the definite lack of a clear definition of intellectuals, they are identified as "people with conscious intellectual activity." As power and the sense of resistance are an entirely political notion, whenever talking about any kind of inequality, intellectuals are found to be born political, that is, to be inherently political. In the case of the Sundarban-Rampal Anti Power-Plant Movement, the civil intellectuals' strength perhaps matters less in some aspects: Rather, this case illustrates the presence and pursuits of having 'voices' that seek the government's accountability in the exercise of power and emphasizing the questioning of authority. 
Acknowledgments: The author would like to convey the genuine gratitude to all the 49 interviewees and all participants of seven groups for focus discussion, to the members of the National Committee Bangladesh (NCBD) for helping in participation-observation, for conducting this research. Besides, the author is thankful to the local people of the affected area for providing cooperation in this issue. Quite importantly, the author conveys special gratitude to the Japanese Ministry of Education, Culture, Sports, Science and Technology (MEXT) for the scholarship program and kind supports. Regarding the publication, the published version of the manuscript is read and agreed.

Conflicts of Interest: In this article, the author declares no conflict of interest. Additionally, it is also assured that there is no specific role of any founding sponsors in this particular research.

\section{References}

1. Kumar, C. Bangladesh power plant struggle calls for international solidarity. The Huffington Post. 24 September 2013. Available online: https://www.huffingtonpost.com/chaitanya-kumar/bangladesh-powerplant-st_b_3983560.html (accessed on 15 January 2019).

2. Bangladesh-India Friendship Power Company (Pvt.) Limited (BIFPCL). A Brief Glimpse of the Company $\mathcal{E}$ Its Endeavors (Brochure); BIFPCL: Dhaka, Bangladesh, 2017; Available online: https://bifpcl.com/about.aspx? mode=company (accessed on 27 May 2019).

3. Banktrack. Rampal Coal Power Plant. 2016. Available online: https://www.banktrack.org/show/dodgydeal/ rampal\#main=updates\&popover=financiers (accessed on 16 June 2019).

4. Banktrack. Equator Principles: Analysis of the Rampal Coal Fired Power Plant Project, Bangladesh. In Equator Principles Analysis Report; Banktrack: East Sussex, UK, 2015; Available online: https://www.banktrack.org/download/rampal_equator_principles_full_analysis_pdf/ rampal_equator_principles_full_analysis.pdf (accessed on 27 May 2019).

5. South Asians for Human Rights. Report on the Fact Finding Mission to Rampal, Bangladesh; South Asians for Human Rights: Colombo, Sri Lanka, 2015; Available online: http://www.southasianrights.org/?p=9066 (accessed on 27 May 2019).

6. 10 questions: Authorities answers', counter response. The Daily Star. 7 September 2016. Available online: https://www.thedailystar.net/frontpage/10-questions-authorities-answers-counter-response-1281937 (accessed on 27 May 2019).

7. Chowdhury, A.H. Environmental impact of coal based power plant of Rampal on the Sundarbans (world's largest mangrove forest) and surrounding areas. MOJES 2017, 2, 85-98. [CrossRef]

8. Pinaki Roy. The Third Pole. 25 April 2018. Available online: https://www.thethirdpole.net/en/2018/04/25/ bangladesh-allows-nearly-200-polluting-factories-near-sundarbans/. (accessed on 12 September 2019).

9. National Committee to Protect Oil, Gas and Mineral Resources, Power, and Ports of Bangladesh. Bidyut Utpadoner Onek Bikalpa ache Sundarban er Kono Bikapla Nei; There are many alternative ways for power generation, but there is no alternative to the Sundarbans; National Committee to Protect Oil, Gas and Mineral Resources, Power, and Ports of Bangladesh: Dhaka, Bangladesh, 2013.

10. National Committee to Protect Oil, Gas and Mineral Resources, Power, and Ports of Bangladesh. Why we need to raise [our] voice against Rampal and Orion coal fired power plants to save Sundarbans? Eng Sheikh Muhammad Shohidulla. 10 March 2016. Available online: http://ncbd.org/wp-content/uploads/2016/03/ National-committee-Booklet-eng-v2.pdf (accessed on 27 May 2019).

11. Faruque, M.O. Neoliberal resource governance and counter-hegemonic social movement in Bangladesh. Soc. Mov. Stud. 2017, 16, 254-259. [CrossRef]

12. McCarthy, J.D.; Zald, M.N. Resource mobilization and social movements: A partial theory. Am. J. Sociol. 1977, 82, 1212-1241. [CrossRef]

13. Touraine, A. An introduction to the study of social movements. Soc. Res. 1985, 52, 749-787. Available online: http://www.jstor.org/stable/40970397 (accessed on 27 May 2019).

14. Turner, R.H. The theme of contemporary social movements. Br. J. Sociol. 1969, 20, 390-405. [CrossRef]

15. Turner, R.H. Figure and ground in the analysis of social movements. Symb. Interact. 1983, 6, 175-181. [CrossRef]

16. Killian, L.M. Organization, Rationality and Spontaneity in the Civil Rights Movement. Am. Sociol. Rev. 1984, 49, 770-783. Available online: http://www.jstor.org/stable/2095529 (accessed on 27 May 2019). [CrossRef]

17. Touraine, A. The importance of social movement. Soc. Mov. Stud. 2002, 1, 89-95. [CrossRef] 
18. Melucci, A. Challenging Codes: Collective Action in the Information Age; Cambridge University Press: Cambridge, UK, 1996; Available online: http://voidnetwork.gr/wp-content/uploads/2016/09/Challenging-CodesCollective-Collective-action-in-the-information-age-by-Alberto-Melucci.pdf (accessed on 6 September 2019).

19. Proietto, R. New social movements: Issues for sociology. Soc. Sci. Inf. 1995, 34, 355-388. [CrossRef]

20. Diani, M. The concept of social movement. Sociol. Rev. 1992, 40, 1-25. [CrossRef]

21. Porta, D.D.; Diani, M. Social Movements: An Introduction; Blackwell Publishing: Oxford, UK, 2006.

22. Arifi, B.; Späth, P. Sleeping on coal: Trajectories of promoting and opposing a lignite-fired power plant in Kosovo. Energy Res. Soc. Sci. 2018, 41, 118-127. [CrossRef]

23. Mishra, N.; Das, N. Coal mining and local environment: A study in Talcher coalfield of India. Air Soil Water Res. 2017, 10. [CrossRef]

24. Luthfa, S. Transnational ties and reciprocal tenacity: Resisting mining in Bangladesh with transnational coalition. Sociology 2017, 5, 127-145. [CrossRef]

25. Brock, A.; Dunlap, A. Normalising corporate counterinsurgency: Engineering consent, managing resistance and greening destruction around the Hambach coal mine and beyond. Political Geogr. 2018, 62, 33-47. [CrossRef]

26. Purcell, T.F.; Martinez, E. Post-neoliberal energy modernity and the political economy of the landlord state in Ecuador. Energy Res. Soc. Sci. 2018, 41, 12-21. [CrossRef]

27. Persson, S.; Harnesk, D.; Islar, M. What local people? Examining the Gállok mining conflict and the rights of the Sámi population in terms of justice and power. Geoforum 2017, 86, 20-29. [CrossRef]

28. Luthfa, S. "Everything Changed after the 26th": Emotion and Obligation in Mobilising Against Phulbari Coal Project in Bangladesh. Bangladesh Sociological Association, TSC; University of Dhaka: Dhaka, Bangladesh, 2012; Available online: https:/www.academia.edu/19874689/_Everything_Changed_after_the_26th_Emotion_ and_Obligation_in_Mobilizing_against_the_Phulbari_Coal_Mine_in_Bangladesh (accessed on 27 May 2019).

29. Roy, A.D. Shahbag stolen? Third force dynamics and electoral politics in Bangladesh. South Asia Res. 2018, 38. [CrossRef]

30. Zaman, F. Agencies of social movements: Experiences of Bangladesh's Shahbag Movement and Hefazat-e-Islam. J. Asian Afr. Stud. 2016, 53. [CrossRef]

31. Sabur, S.; Postcard from Shahbag. ISA e-Symposium Sociology. 2013. Available online: https://www.isasociology.org/uploads/files/EBul-Sabur-March2012.pdf (accessed on 11 January 2019).

32. Kabir, A.H.; Greenwood, J. Neoliberalism, violence and student resistance in the higher education sector in Bangladesh. Soc. Cult. South Asia 2017, 3, 68-91. [CrossRef]

33. Abdullah, T. Rastra Banam Kishor Bidroho; Teen Revolution against the State; Chaitannya Prokashon: Sylhet, Bangladesh, 2019.

34. Young, R. Michel Foucault: The Order of Discourse: Untying the Texts: A Post-Structuralist Reader; Routledge \& Kegan Paul Ltd.: Boston, MA, USA, 1981.

35. Rabinow, P. The Foucault Reader; Pantheon Books: New York, NY, USA, 1984.

36. Hindess, B. Discourse of Power: From Hobbs to Foucault; Blackwell Publishers Ltd.: Oxford, UK, 1996.

37. Smith, P. Cultural theory: An introduction; Blackwell Publishers Ltd.: Malden, MA, USA, 2001; pp. 4-5.

38. Baumgarten, B.; Ullrich, P. Discourse, power and governmentality. Social movement research with and beyond Foucault. In Social Theory and Social Movements; Social Science Research Center Berlin (WZB): Berlin, Germany, 2012; Available online: https://depositonce.tu-berlin.de/bitstream/11303/4865/1/baumgarten_et-al. pdf (accessed on 30 May 2019).

39. Pey, P.; Islam, M.S. Eco-governmentality: A discursive analysis of State-NGOs-youth relations in Singapore. Soc. Sci. J. 2017, 6, 133. [CrossRef]

40. Bates, T.R. Gramsci and the theory of hegemony. J. Hist. Ideas 1975, 36, 351-366. [CrossRef]

41. McCoy, T.S. Hegemony, power, media: Foucault and cultural studies. Communications 1988, 14. [CrossRef]

42. Faubion, J.D. Governmentality. In Power: Essential Works of Foucault 1954-1984; Hurley, R., Ed.; Penguin Books: London, UK, 1994; Volume 3.

43. Gledhill, J. The power of ethnic nationalism: Foucault's bio-power and the development of ethnic nationalism in Eastern Europe. Natl. Identities 2005, 7, 347-368. [CrossRef]

44. Makarychev, A.; Yatsyk, A. Biopolitics and national identities: Between liberalism and totalization. J. Nationl. Ethn. 2017, 45, 1-7. [CrossRef] 
45. Macky, D. Rethinking Biopolitics, Race and Power in the Wake of Foucault. Theory Cult. Soc. 2009, 26, 186-205. [CrossRef]

46. Dean, M. Governmentality: Power and Rule in Modern Society; Sage: London, UK, 2010; p. 21.

47. Dawson, J.I. The two faces of environmental justice: Lessons from the eco-nationalist phenomenon. Environ. Politics 2000, 9, 22-60. [CrossRef]

48. Guha, R. Environmentalism: A Global History; Longman: New York, NY, USA, 2000.

49. Eriksen, T.H.; Nielsen, F.S. A History of Anthropology; Pluto Press: London, UK, 2001; pp. 1-110.

50. Singh, B.; Guyer, J.I. A joyful history of anthropology. HAU J. Ethnogr. Theory 2016, 2016. 6, $197-211$. [CrossRef]

51. Hart, K.J. The Art of 'Governing Nature': 'Green' Governmentality and the Management of Nature. Unpublished Master's Thesis, Queen's University, Kingston, ON, Canada, 2011. Available online: https://qspace.library.queensu.ca/bitstream/handle/1974/6780/Hart_Kristan_J_201109_MES.pdf? sequence $=1 \&$ is Allowed $=y$ (accessed on 31 May 2019).

52. Zake, I. The construction of national(ist) subject: Applying the ideas of Louis Althusser and Michel Foucault to nationalism. Soc. Thought Res. Postmod. Glob. Politics 2002, 25, 217-246. Available online: http://www.jstor.org/stable/23250012 (accessed on 31 May 2019).

53. Kelly, M. G E. The Political Philosophy of Michel Foucault; Routledge: London, UK, 2009; pp. 65-68.

54. Hoare, Q.; Smith, G.N. Selections from the Prison Notebooks of Antonio Gramsci; Lawrence and Wishart: London, UK, 1999; pp. 131-132.

55. Spivak, G.C. Can the subaltern speak? In Marxism and the Interpretation of Culture; Nelson, C., Grossberg, L., Eds.; Macmillan: London, UK, 1988.

56. Maggio, J. “Can the subaltern be heard?" Political theory, translation, representation, and Gayatri Chakravorty Spivak. Alternatives 2007, 32, 419-443. [CrossRef]

57. Singh, S.; Menon, M.; Dutta, P.K.; Pati, B.; Barik, R.; Chopra, R.; Dutta, P.; Prasad, S. Subaltern studies II: A review article. Soc. Sci. (New Delhi) 1984, 12, 3-41. [CrossRef]

58. Sarkar, S. Writing Social History; Oxford University Press: New Delhi, India, 1997.

59. Villadsen, K. Michel Foucault and the forces of civil society. Theory Cult. Soc. 2015, 33. [CrossRef]

60. Gordon, C. Power/Knowledge: Selected Interviews and other Writings 1972-1977; Foucault, M., Ed.; Pantheon Books: New York, NY, USA, 1980; pp. 81-82.

61. Buttigieg, J.A. The contemporary discourse on civil society: A Gramscian critique. Boundary 2005, 2, 33-52. [CrossRef]

62. Baud, M.; Rutten, R. Popular Intellectuals and Social Movements: Framing Protest in Asia, Africa, and Latin America; International Review of Social History Supplements, No. 12; Cambridge University Press: Cambridge, UK, 2004; p. 5.

63. Russell, B.H. Research Methodology in Anthropology; Altamira: Walnut Creek, CA, USA, 1995; p. 209.

64. Clifford, J.; Marcus, G.E. Writing Culture: The Poetics and Politics of Ethnography; The University of California Press: Berkeley, CA, USA, 1986; pp. 1-7.

65. Atkinson, P.; Coffey, A.; Delamont, S.; Lofland, J.; Lofland, L. Handbook of Ethnography; Sage Publications Ltd.: London, UK, 2001; pp. 39-59.

66. Van Dijk, T.A. Discourse, power and access. In Texts and Practices; Caldas-Coulthard, C.R., Coulthard, M., Eds.; Routledge: London, UK, 1996; pp. 84-104. 20p, Available online: http://www.discourses.org/OldArticles/ Discourse,\%20power\%20and\%20access.pdf (accessed on 14 June 2019).

67. Karlberg, M. The power of discourse and the discourse of power: Pursuing peace through discourse intervention. Int. J. Peace Dev. Stud. 2005, 10, 1-25. Available online: http://www.gmu.edu/programs/icar/ ijps/vol10_1/Karlberg_101IJPS.pdf (accessed on 14 June 2019).

68. Center for Environmental and Geographic Information Services (CEGIS). Final Report on Environmental Impact Assessment Report on 2x (500-660) MW Coal Based Thermal Power Plant to be Constructed at the Location of Khulna; Environmental Impact Assessment Report; Governments of the People's Republic of Bangladesh, Ministry of Power, Energy and Mineral Resources (Power Division), and Bangladesh Power Development Board: Dhaka, Bangladesh, 2013.

69. Heritage in danger: UNESCO to put Sundarbans on the list. The Daily Star. 15 June 2019. Available online: https://www.thedailystar.net/backpage/unesco-put-sundarbans-in-bangladesh-on-the-heritage-indanger-list-1757194 (accessed on 15 June 2019). 
70. Dhaka Tribune. Mizanur Rahman. HC orders DoE to give permission for set up of factories in Sundarbans ECA. Djaka Tribune. 27 August 2019. Available online: https://www.dhakatribune. com/bangladesh/court/2019/08/27/hc-gives-permission-to-set-up-factories-in-sundarbans-eca?fbclid= IwAR2nFao4pgOk691OvA-qnIMmWu1FBVnURD5A9s928kVHNGVxl2U57QNUlrw (accessed on 12 September 2019).

71. Fraser, G. Foucault, governmentality theory and "neoliberal community development". Community Dev. J. 2018. [CrossRef]

72. Whitfield, D. In Place of Austerity: Reconstructing the Economy, State and Public Services; Spokesman Books: Nottingham, UK, 2012.

73. Huq, M.A.A. New paradigm of tripartite connectivity: Civil intellectuals, resistance, and the collective social movement. J. IDEC 2019, 26, 29-49. Available online: https://www.hiroshima-u.ac.jp/system/files/124720/03. pdf (accessed on 16 June 2019).

74. March to PMO foiled, 6 held from 'Save Sundarbans' demo. The Daily Star. 28 July 2016. Available online: https://www.thedailystar.net/city/demo-sundarbans-foiled-10-held-1260748 (accessed on 16 June 2019).

75. Lupton, D. Discourse analysis: A new methodology for understanding the ideologies of health and illness. Austr. J. Pub. Health 1992, 16, 145-150. [CrossRef]

76. Powers, P. The philosophical foundations of Foucaultian discourse analysis. Crit. Approaches Discourse Anal. Across Discip. 1996, 1, pp. 18-34. Available online: https://www.lancaster.ac.uk/fass/journals/cadaad/wpcontent/uploads/2015/01/Volume-1_Powers.pdf (accessed on 16 June 2019).

77. Kiros, T. Toward the Construction of a Theory of Political Action: Antonio Gramsci; University Press of America: Lanham, MD, USA, 1985; pp. 101-102.

78. Oladipo, E.O. Potential Impacts of Climatic Change Nigeria; Presented at the Geography week of NAGS; ABU: Zaria, Nigeria, 1991.

79. Heywood, A. Political Ideologies: An Introduction, 4th ed.; Palgrave Macmillan: New York, NY, USA, 2007.

80. Obo, U.B.; Coker, M.A. The Marxist theory of the state: An introductory guide. MJSS 2014, 5. Available online: https://www.mcser.org/journal/index.php/mjss/article/viewFile/2243/2229 (accessed on 17 June 2019). [CrossRef]

81. O'Connor, J. Marxism and the three movements of neoliberalism. Crit. Sociol. 2010, 36, 691-715. [CrossRef]

82. Mita Mehdi. Facebook Post. 22 August 2016. Available online: https://www.facebook.com/photo.php?fbid= 1683800771635528\&set=a.1409373679078240\&type=3\&theater (accessed on 11 September 2019).

83. Bose, S. The Nation as Mother and Other Visions of Nationhood; Penguin Random House India Private Ltd.: Haryana, India, 2017; pp. 9-12.

84. Lasslett, $\mathrm{K}$. The state at the heart of capitalism: Marxist theory and Foucault's lectures on governmentality. Crit. Sociol. 2014, 41, 641-658. [CrossRef]

85. Basu, P. Michel Foucault: Shesh Porjayer Tottyovabna; Michel Foucault: Thoughts on Theories for Last Period; Oxford University Press: New Delhi, India, 2019; pp. 135-137.

86. Ahmed, M.U.; The historic movement to save Sundarbans. Which side are you on? The Daily Star. 28 April 2017. Available online: https://www.thedailystar.net/star-weekend/environment/the-historic-movementsave-sundarbans-1397413 (accessed on 7 February 2020).

87. Davidson, D.J.; Frickel, S. Understanding environmental governance. Organ. Environ. 2004, 17, 471-492. [CrossRef]

88. Lorenzini, D. Governmentality, subjectivity, and the neoliberal form of life. J. Cult. Res. 2018, 22, 154-166. [CrossRef]

89. A power plant like Rampal would never be allowed in India. Dhaka Tribune. 23 August 2016. Available online: https://www.dhakatribune.com/uncategorized/2016/08/23/power-plant-like-rampal-never-allowedindia (accessed on 17 June 2019).

90. Biebricher, T. The practices of theorists: Habermas and Foucault as public intellectuals. Philos. Soc. Crit. 2011, 37, 709-734. [CrossRef]

91. Biebricher, T. Foucault and the politics of rights. J. Political Power 2012, 5, 301-318. [CrossRef]

92. Bove, P.A. Intellectuals at war: Michel Foucault and the analytics of power. SubStance 1983, 11, 36-55. [CrossRef]

93. Islam, M.N.; Al-Amin, M. The Rampal Power Plant, Ecological Disasters and Environmental Resistance in Bangladesh. Int. J. Environ. Stud. 2019, 76, 922-939. [CrossRef] 
94. Goldstein, H. The "search for subjugated knowledge" reconsidered. Soc. Work 1993, 38, 643-645. Available online: https://www.jstor.org/stable/23717166 (accessed on 18 June 2019).

95. Kant, I. An answer to the question: What is Enlightenment? In Kant: Political Writings; Nisbet, H.B., Reiss, H., Eds.; Penguin Books: Cambridge, UK, 1991; pp. 54-60.

96. Harpham, G.G. So ... What is Enlightenment? An inquisition into modernity. Crit. Inq. 1994, 20, 524-556. Available online: http://www.jstor.org/stable/1343868 (accessed on 19 June 2019).

97. Baert, P.; Morgan, M. A performative framework for the study of intellectuals. Eur. J. Soc. Theory 2017, 21, 322-339. [CrossRef]

98. Boggs, C. Marxism and the role of intellectuals. Political Sci. 1979, 1, 7-23. [CrossRef]

99. Brighenti, A.M. Antonio Gramsci's Theory of the Civil Society; Springer Fachmedien Wiesbaden: Wiesbaden, Germany, 2016. [CrossRef]

100. Edelman, M. Social movements: Changing paradigms and forms of politics. Ann. Rev. Anthropol. 2001, 30, 285-317. [CrossRef]

101. Nandy, A. The Romance of the State. And the Fate of Dissent in the Tropics; Oxford University Press: New Delhi, India, 2003.

102. Rootes, C. Environmental movements: From the local to the global. Environ. Politics 1999, 8, 1-12. [CrossRef]

103. Bangladesh uses tear gas, water cannon to break up power plant protest. The Straits Times. 26 January 2017. Available online: https://www.straitstimes.com/asia/south-asia/bangladesh-uses-tear-gas-water-cannon-tobreak-up-power-plant-protest. (accessed on 20 January 2020).

(C) 2020 by the author. Licensee MDPI, Basel, Switzerland. This article is an open access article distributed under the terms and conditions of the Creative Commons Attribution (CC BY) license (http://creativecommons.org/licenses/by/4.0/). 